Article

\title{
Anti-Inflammatory and Antioxidant Activities of Terpene- and Polyphenol-Rich Premna odorata Leaves on Alcohol-Inflamed Female Wistar Albino Rat Liver
}

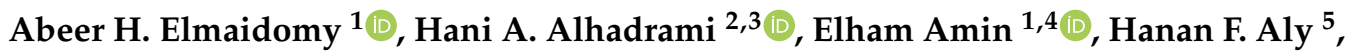 \\ Asmaa M. Othman ${ }^{6}$, Mostafa E. Rateb ${ }^{1,7}$ (D), Mona H. Hetta ${ }^{8}(\mathbb{D}$, \\ Usama Ramadan Abdelmohsen ${ }^{9,10, *}$ and Hossam M. Hassan 1,*(D) \\ 1 Department of Pharmacognosy, Faculty of Pharmacy, Beni-Suef University, Beni-Suef 62514, Egypt; \\ abeerabdelhakium@yahoo.com (A.H.E.); elham_bns@yahoo.com (E.A.); mostafa.rateb@uws.ac.uk (M.E.R.) \\ 2 Department of Medical Laboratory Technology, Faculty of Applied Medical Sciences, King Abdulaziz \\ University, P.O. Box 80402 Jeddah 21589, Saudi Arabi; hanialhadrami@kau.edu.sa \\ 3 Special Infectious Agent Unit, King Fahd Medical Research Centre, King Abdulaziz University, \\ P.O. Box 80402 Jeddah 21589, Saudi Arabia \\ 4 Department of Medicinal Chemistry and Pharmacognosy, College of Pharmacy, Qassim University, \\ Buraydah 51452, Saudi Arabia \\ 5 Therapeutic Chemistry Department, National Research Centre, Cairo 11865, Egypt; \\ hanan_abduallah@yahoo.com \\ 6 Department of Internal Medicine, Faculty of Medicine, Beni-Suef University, Beni-Suef 62514, Egypt; \\ assmaa_med@yahoo.com \\ 7 School of Computing, Engineering \& Physical Sciences, University of the West of Scotland, \\ Paisley PA1 2BE, UK \\ 8 Department of Pharmacognosy, Faculty of Pharmacy, Fayoum University, Fayoum 63514, Egypt; \\ mhm07@fayoum.edu.eg \\ 9 Department of Pharmacognosy, Faculty of Pharmacy, Minia University, Minia 61519, Egypt \\ 10 Department of Pharmacognosy, Faculty of Pharmacy, Deraya University, 7 Universities Zone, \\ New Minia City 61111, Egypt \\ * Correspondence: usama.ramadan@mu.edu.eg (U.R.A.); Hossam.abdelazeem@pharm.bsu.edu.eg (H.M.H.); \\ Tel.: +20-1111595772 (U.R.A.); +20-1065605018 (H.M.H.)
}

Academic Editors: Francesco Cacciola and Thomas J. Schmidt

\begin{abstract}
Premna odorata Blanco (Lamiaceae) is an ethnomedicinal plant native to different tropical regions. Although some reports addressed their anti-inflammatory, cytotoxic, and antituberculotic effects, their hepatoprotective potential is yet to be discovered. Accordingly, this study investigated the crude extract and different fractions of the plant leaves; metabolic profiling using liquid chromatography/high-resolution electrospray ionization mass spectroscopy (LC-HRESIMS) analysis, in silico absorption, distribution, metabolism, excretion, and toxicity (ADMET) properties for the dereplicated metabolite via online PreADMET program, ROS scavenger activity on the Hep G2 human liver cancer cell line, and the possible hepatic cellular treatment effects in alcohol-inflamed liver female Wistar albino rats. Metabolic profiling dereplicated a total of 28 metabolites from the crude extract and its various fractions. In silico ADMET and ROS scavenger activity screening suggested plant metabolites are of potential bioactivity. In vivo hepatic treatment with crude, defatted crude, and n-hexane leave extracts suggested all extracts significantly improved liver damage, which was indicated by the reduction of elevated serum levels of bilirubin, AST, ALT, ALP, CRP, TNF- $\alpha$, ICAM- 1 , VCAM-1, and MDA. The reduced levels of GSH and TAC were normalized during the study. Histological examinations of liver tissue showed collagen fiber distribution nearly back to its normal pattern. The anti-inflammatory and antioxidant potentials of Premna odorata extracts could be partly related to the combined effects of these phytochemicals or their synergistic interactions.
\end{abstract}


Keywords: Premna odorata; LC-HRESIMS; terpene; polyphenolic; ADMET; ROS; TNF- $\alpha$; antioxidant

\section{Introduction}

The liver is primarily responsible for alcohol metabolism in the human body and as this is the case, it is vulnerable to alcohol-related injuries [1]. According to literature, chronic alcohol consumption causes liver cell inflammation which triggers an immune response through recognition of damage-associated molecular patterns (DAMPs). DAMPs signal damage or necrosis through transmembrane toll-like receptors (TLRs), a class of proteins that play a key role in the innate immune system [2]. TLRs are single-pass membrane-spanning receptors usually expressed on sentinel cells such as macrophages and dendritic cells and recognized structurally conserved molecules [2,3]. Once recognition occurs, TLRs activate common signaling pathways that activate the nuclear factor kappa-light-chain-enhancer of activated B cells (NF- $\mathrm{kB}$ ), a key regulator of inflammatory gene expression. This results in the activation of numerous physiological responses: cytokine tumor necrosis factor- $\alpha$ (TNF- $\alpha$ ), C-reactive protein (CRP), interlukin-1 (IL-1), IL-6, IL-12, cell adhesion molecules, such as vascular cell adhesion molecule $\mathbf{1}$ (VCAM-1) and intercellular adhesion molecule 1 (ICAM-1), reactive oxygen species (ROS), inducible nitric oxide synthase (iNOS), and cyclooxygenase II (COX-II) [1,3]. These molecules elicit the production of prostaglandin $\mathrm{E}_{2}\left(\mathrm{PGE}_{2}\right)$, chemokines, and various co-stimulatory molecules which play important roles in the pathogenesis of liver cell inflammation [1]. Moreover, the activity of monocytes and neutrophils improve and migrate to inflammation sites and create a cytotoxic environment by releasing noxious chemicals, including ROS, nitrogen species, and various proteinases, which are destructive to both pathogens and host cells. Liquefaction induction of the surrounding hepatic tissue was also observed, resulting in liver cell damage which led to heat, swelling, pain, and loss of tissue function. This is reflected by elevated serum levels of bilirubin, aspartate aminotransferase (AST), alanine aminotransferase (ALT), and alkaline phosphatase (ALP) [1,3].

On the other hand, ROS are naturally produced by living organisms through negative cellular metabolism [4]. At intermediate concentrations, ROS improve physiological cell processes. However, at high ones, ROS adversely modify cell contents as lipid malondialdehyde (MDA), proteins, and deoxyribonucleic acid (DNA) [4]. ROS are classified as free radicals, where superoxide anion $\left(\mathrm{O}_{2}{ }^{-}\right)$, hydroxyl radical $\left(\mathrm{OH}^{-}\right)$, and hydrogen peroxide $\left(\mathrm{H}_{2} \mathrm{O}_{2}\right)$ are considered physiologically significant ROS [4]. The human body naturally contains a variety of antioxidants which counterbalance the effect of ROS such as catalase, glutathione peroxidase (GSH-Px), vitamins (A, C and E), $\beta$-carotene, and glutathione (GSH) [4]. As previously indicated, direct liver cell damage that occurs during chronic alcohol consumption is caused by free radicals [5]. In a healthy individual with no liver damage, free radicals are quickly scavenged by natural protective antioxidants (GSH, GSH-Px, vitamins A and E), yet in chronic alcohol consumption individuals, levels of these naturally occurring antioxidants are reduced, GSH being the most affected [5]. Consequently, chronic inflammation progress by ROS could cause organ dysfunction, especially when this process targets important organs like liver [4]. Detecting liver function tests (bilirubin, AST, ALT, and ALP), pro-inflammatory markers (IL-1 $\beta$, IL-6, IL-10, TNF- $\alpha$, CRP, nitric oxide (NO), ICAM-1, VCAM-1, and COX-II), oxidative stress marker levels, and antioxidant tests (MDA, $\mathrm{H}_{2} \mathrm{O}_{2}$, GSH-Px, catalase, GSH, and total antioxidant capacity (TAC)) are important steps to determine how much an organ is damaged [1].

Liver disease is a life-threatening disease with elevated mortality rates [6]. Current approaches to treatment, including drug therapy and liver transplantation, feature limited efficacy and risky complications [6]. These concerns have stimulated the search for alternative safe and effective drugs, especially natural drugs, due to their potential in treatment of various forms of hepatopathy [7]. Premna odorata is an ethnobotanical plant native to different tropical regions. As a folk medicine, a decoction of its leaves has been used as a febrifuge, diuretic, carminative, and to treat vaginal 
irritation, abdominal pains, coughing, and dysentery [8]. A limited number of investigations have been carried out on the Premna genus, particularly on the Premna odorata species, where iridoids, phenylethanoids, flavonoids, and acylated rhamnopyranosides were preliminary described as its main active constituents [9-12]. Additional studies also addressed their anti-inflammatory, cytotoxic, and anti-tuberculosis effects [9,13-16]. However, their hepatoprotective potential is yet to be explored. Therefore, this study investigated the crude extract and different fractions of the plant leaves; metabolomics profiling using liquid chromatography/high-resolution electrospray ionization mass spectroscopy (LC-HRESIMS), in silico absorption, distribution, metabolism, excretion, and toxicity (ADMET) properties for the dereplicated metabolites, ROS scavenger activity, and the possible hepatic cellular treatment effects in alcohol-inflamed liver female Wistar albino rats.

\section{Results}

\subsection{Metabolomic Analysis}

Chemical profiling of the secondary metabolites of Premna odorata leaves using LC-HRESIMS for dereplication purposes resulted in the characterization of a variety of constituents, including sterols, triterpenes, fatty acids, iridoids, flavones, and phenylethanoids (Table 1, Figure 1). From the metabolomics data, the ion at mass-to-charge ratio $(\mathrm{m} / \mathrm{z}) 433.1361$ corresponding to the suggested molecular formula $\mathrm{C}_{21} \mathrm{H}_{20} \mathrm{O}_{10}$ was dereplicated as vitexin (1) $[9,17]$, which was formerly reported in Premna odorata. Two acylated iridoid glycosides with the molecular formula $\mathrm{C}_{39} \mathrm{H}_{44} \mathrm{O}_{20}$ and $\mathrm{C}_{30} \mathrm{H}_{38} \mathrm{O}_{17}$ were characterized as premnoside $\mathrm{A}$ (2) and 6-O- $\alpha$-L-(2"-O-trans-caffoyl) rhamnopyranosyl catalpol (3) from the ions at $\mathrm{m} / \mathrm{z} 833.2746$ and 671.1910 , respectively, which were previously reported in Premna odorata [11,12]. Furthermore, the ion at $\mathrm{m} / \mathrm{z} 577.1969$ with the corresponding predicted molecular formula $\mathrm{C}_{35} \mathrm{H}_{60} \mathrm{O}_{6}$ was dereplicated as the steroidal glycoside daucosterol (4), which was earlier isolated from Premna japonica, whereas herein, it is reported from the Premna odorata plant for the first time [18]. Additional sterols, triterpenes, fatty acids, iridoids, phenylethanoids, and flavone-related compounds which were formally isolated from Premna odorata leaves were also characterized as compounds 5-7, 9-11, 13-16, 18, 19-22, and 24-26 based on the ions and the corresponding predicted molecular formulas (Table 1, Figure 1) [8-11,19]. The ions at $\mathrm{m} / \mathrm{z} 669.1634$ and 685.2780 with the predicted molecular formulas $\mathrm{C}_{31} \mathrm{H}_{40} \mathrm{O}_{16}$ and $\mathrm{C}_{31} \mathrm{H}_{40} \mathrm{O}_{17}$ were dereplicated as the iridoid glycosides $6-O-\alpha-\mathrm{L}-(2$ "-O-trans-p-methoxycinnamoyl) rhamnopyranosyl catalpol (8) and 6-O- $\alpha$-L-(4"-O-trans-feruloyl) rhamnopyranosyl catalpol (12) [18], which were first reported in the Premna genus. Likewise, iridoids with the molecular formula $\mathrm{C}_{42} \mathrm{H}_{64} \mathrm{O}_{20}$ and $\mathrm{C}_{45} \mathrm{H}_{58} \mathrm{O}_{24}$ were identified as premnaodoroside D (23) [20] and premcoryoside (27) [21], which were reported for the first time in the Premna genus. Furthermore, the ions at $\mathrm{m} / \mathrm{z} 277.1807$, and 489.2793 with the suggested molecular formulas $\mathrm{C}_{18} \mathrm{H}_{30} \mathrm{O}_{2}$ and $\mathrm{C}_{30} \mathrm{H}_{48} \mathrm{O}_{5}$ were identified as the unsaturated fatty acid linolenic acid and the pentacyclic triterpene arjunolic acid (13 and 28, respectively) [22]. It is worth mentioning that based on dereplication, sterols, triterpenes, and the fatty acid were predominantly in the n-hexane (n-hex) fraction, while iridoids, flavones, and phenylethanoids were the major metabolites in the dichloromethane (DCM), ethyl acetate (EtOAC), and n-butanol fractions (Table 1, Figure 1). 
Table 1. The liquid chromatography/high-resolution electrospray ionization mass spectroscopy (LC-HRESIMS) dereplication results of the crude Premna odorata leave extract and fractions (n-hexane, dichloromethane, ethyl acetate, n-butanol).

\begin{tabular}{|c|c|c|c|c|c|c|c|c|c|c|c|}
\hline No. & Identified & Source & MF & $t_{R}(\min )$. & $m / z$ & Adduct & $\mathrm{CE}$ & $\mathbf{H}$ & DCM & EtOAC & $\mathbf{B}$ \\
\hline 1 & Vitexin & Premna odorata & $\mathrm{C}_{21} \mathrm{H}_{20} \mathrm{O}_{10}$ & 9.71 & 433.1361 & {$[\mathrm{M}+\mathrm{H}]^{+}$} & + & & & & + \\
\hline 2 & Premnoside A & Premna odorata & $\mathrm{C}_{39} \mathrm{H}_{44} \mathrm{O}_{20}$ & 11.37 & 833.2746 & {$[\mathrm{M}+\mathrm{H}]^{+}$} & + & & & + & + \\
\hline 3 & 6- O- $\alpha$ - L-(2"-O-trans-caffoyl) rhamnopyranosyl catalpol & Premna odorata & $\mathrm{C}_{30} \mathrm{H}_{38} \mathrm{O}_{17}$ & 11.98 & 671.1910 & {$[\mathrm{M}+\mathrm{H}]^{+}$} & + & & & + & + \\
\hline 4 & Daucosterol & Premna japonica & $\mathrm{C}_{35} \mathrm{H}_{60} \mathrm{O}_{6}$ & 12.33 & 577.1969 & {$[\mathrm{M}+\mathrm{H}]^{+}$} & + & + & & & \\
\hline 5 & Premnoside D & Premna odorata & $\mathrm{C}_{39} \mathrm{H}_{44} \mathrm{O}_{19}$ & 12.61 & 817.2282 & {$[\mathrm{M}+\mathrm{H}]^{+}$} & + & & & + & + \\
\hline 6 & Premnoside $\mathrm{H}$ & Premna odorata & $\mathrm{C}_{39} \mathrm{H}_{44} \mathrm{O}_{18}$ & 13.00 & 801.2404 & {$[\mathrm{M}+\mathrm{H}]^{+}$} & + & & & + & + \\
\hline 7 & Premnoside C & Premna odorata & $\mathrm{C}_{40} \mathrm{H}_{46} \mathrm{O}_{19}$ & 13.09 & 831.2411 & {$[\mathrm{M}+\mathrm{H}]^{+}$} & + & & & + & + \\
\hline 8 & 6- O- $\alpha$ - L-(2"-O-trans-p-methoxycinnamoyl) rhamnopyranosyl catalpol & Premna japonica & $\mathrm{C}_{31} \mathrm{H}_{40} \mathrm{O}_{16}$ & 13.20 & 669.1634 & {$[\mathrm{M}+\mathrm{H}]^{+}$} & + & & & + & + \\
\hline 9 & Stigmasterol & Premna odorata & $\mathrm{C}_{29} \mathrm{H}_{48} \mathrm{O}$ & 13.33 & 413.2619 & {$[\mathrm{M}+\mathrm{H}]^{+}$} & + & + & & & \\
\hline 10 & Acacetin & Premna odorata & $\mathrm{C}_{16} \mathrm{H}_{12} \mathrm{O}_{5}$ & 13.60 & 285.1126 & {$[\mathrm{M}+\mathrm{H}]^{+}$} & + & & & + & \\
\hline 11 & Premnoside G & Premna odorata & $\mathrm{C}_{39} \mathrm{H}_{44} \mathrm{O}_{18}$ & 13.72 & 801.2404 & {$[\mathrm{M}+\mathrm{H}]^{+}$} & + & & & + & + \\
\hline 12 & 6- O- $\alpha$ - L-(4"-O-trans-feruloyl) rhamnopyranosyl catalpol & Premna japonica & $\mathrm{C}_{31} \mathrm{H}_{40} \mathrm{O}_{17}$ & 13.78 & 685.2780 & {$[\mathrm{M}+\mathrm{H}]^{+}$} & + & & & + & + \\
\hline 13 & $\beta$-sitosterol & Premna odorata & $\mathrm{C}_{29} \mathrm{H}_{50} \mathrm{O}$ & 14.19 & 414.1849 & {$[\mathrm{M}+\mathrm{H}]^{+}$} & + & + & & & \\
\hline 14 & Verbascoside & Premna odorata & $\mathrm{C}_{29} \mathrm{H}_{36} \mathrm{O}_{15}$ & 14.47 & 625.1396 & {$[\mathrm{M}+\mathrm{H}]^{+}$} & + & & & + & + \\
\hline 15 & Premnoside F & Premna odorata & $\mathrm{C}_{41} \mathrm{H}_{48} \mathrm{O}_{18}$ & 14.54 & 829.2011 & {$[\mathrm{M}+\mathrm{H}]^{+}$} & + & & & + & + \\
\hline 16 & Premnoside E & Premna odorata & $\mathrm{C}_{41} \mathrm{H}_{48} \mathrm{O}_{18}$ & 14.73 & 829.2011 & {$[\mathrm{M}+\mathrm{H}]^{+}$} & + & & & + & + \\
\hline 17 & Linolenic acid & Premna microphylla & $\mathrm{C}_{18} \mathrm{H}_{30} \mathrm{O}_{2}$ & 14.81 & 277.1807 & {$[\mathrm{M}-\mathrm{H}]^{+}$} & + & + & & & \\
\hline 18 & Diosmetin & Premna odorata & $\mathrm{C}_{16} \mathrm{H}_{12} \mathrm{O}_{6}$ & 15.09 & 301.2947 & {$[\mathrm{M}+\mathrm{H}]^{+}$} & + & & + & + & \\
\hline 19 & Premnaodoroside A & Premna odorata & $\mathrm{C}_{42} \mathrm{H}_{66} \mathrm{O}_{20}$ & 15.94 & 891.3561 & {$[\mathrm{M}+\mathrm{H}]^{+}$} & + & & + & & \\
\hline 20 & Premnaodoroside B & Premna odorata & $\mathrm{C}_{42} \mathrm{H}_{66} \mathrm{O}_{19}$ & 16.06 & 875.2437 & {$[\mathrm{M}+\mathrm{H}]^{+}$} & + & & + & & \\
\hline 21 & Premnaodoroside C & Premna odorata & $\mathrm{C}_{42} \mathrm{H}_{64} \mathrm{O}_{19}$ & 16.12 & 873.3192 & {$[\mathrm{M}+\mathrm{H}]^{+}$} & + & & + & & \\
\hline 22 & Premnoside D & Premna odorata & $\mathrm{C}_{40} \mathrm{H}_{46} \mathrm{O}_{20}$ & 16.21 & 847.2782 & {$[\mathrm{M}+\mathrm{H}]^{+}$} & + & & & + & + \\
\hline 23 & Premnaodoroside D & Premna subscandens & $\mathrm{C}_{42} \mathrm{H}_{64} \mathrm{O}_{20}$ & 17.74 & 889.2297 & {$[\mathrm{M}+\mathrm{H}]^{+}$} & + & & + & & \\
\hline 24 & B-amyrin & Premna odorata & $\mathrm{C}_{30} \mathrm{H}_{50} \mathrm{O}$ & 18.28 & 465.2018 & {$[\mathrm{M}+\mathrm{K}]^{+}$} & + & + & & & \\
\hline 25 & Luteolin & Premna odorata & $\mathrm{C}_{15} \mathrm{H}_{10} \mathrm{O}_{6}$ & 18.66 & 309.2349 & {$[\mathrm{M}+\mathrm{Na}]^{+}$} & + & & + & + & \\
\hline 26 & Apigenin & Premna odorata & $\mathrm{C}_{15} \mathrm{H}_{10} \mathrm{O}_{5}$ & 20.82 & 293.2147 & {$[\mathrm{M}+\mathrm{Na}]^{+}$} & + & & & + & \\
\hline 27 & Premcoryoside & Premna corymbosa & $\mathrm{C}_{45} \mathrm{H}_{58} \mathrm{O}_{24}$ & 21.52 & 983.4891 & {$[\mathrm{M}+\mathrm{H}]^{+}$} & + & & & & + \\
\hline 28 & Arjunolic acid & Premna microphylla & $\mathrm{C}_{30} \mathrm{H}_{48} \mathrm{O}_{5}$ & 21.64 & 489.2793 & {$[\mathrm{M}+\mathrm{H}]^{+}$} & + & + & & & \\
\hline
\end{tabular}

MF: molecular formula, $\mathrm{t}_{\mathrm{R}}$ : retention time, min.: minute, $\mathrm{CE}$ : crude extract, $\mathrm{H}$ : $\mathrm{n}$-hexane fraction, DCM: dichloromethane fraction, EtOAC: ethyl acetate fraction, B: $\mathrm{n}$-butanol fraction. 

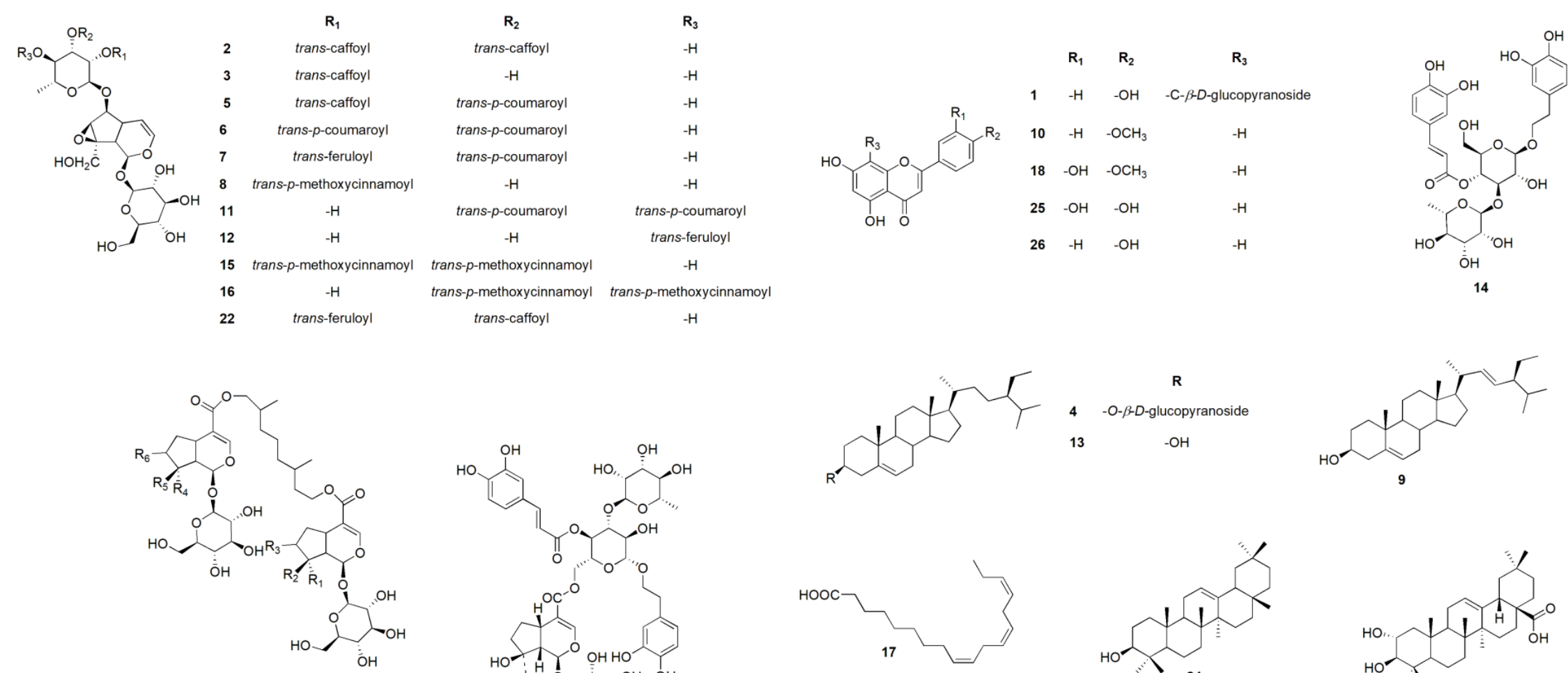

$\begin{array}{llllll}R_{1} & R_{2} & R_{3} & R_{4} & R_{5} & R_{6}\end{array}$
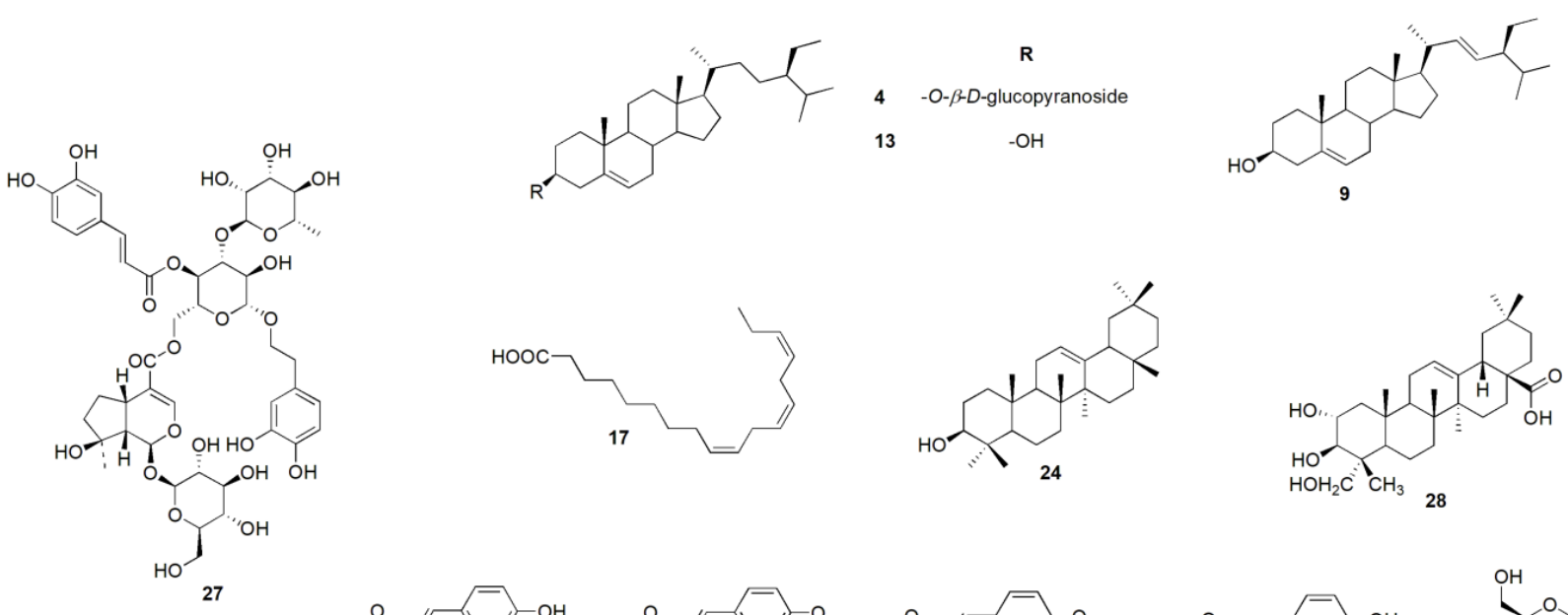

$19 \begin{array}{llllllll} & -\mathrm{CH}_{3} & -\mathrm{OH} & -\mathrm{H} & -\mathrm{CH}_{3} & -\mathrm{OH} & -\mathrm{H}\end{array}$

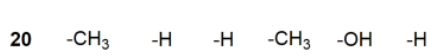

$21=\mathrm{CH} 2 \quad-H_{2} \quad-\mathrm{CH}_{3} \quad-\mathrm{OH} \quad-\mathrm{H}$

$23=\mathrm{CH}_{2} \quad-\mathrm{OH} \quad-\mathrm{CH}_{3} \quad-\mathrm{H} \quad-\mathrm{OH}$
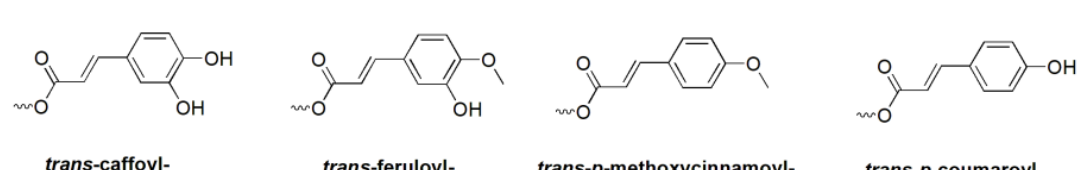

$\underbrace{\mathrm{O}}_{\mathrm{OH}} \mathrm{OH}$

Figure 1. Dereplicated metabolites from the LC-HRESIMS analysis of the crude Premna odorata leave extract and fractions. 


\subsection{In Silico ADMET Properties for the Crude Extract of Different Premna odorata Metabolites}

In silico predicted ADMET profiling of the dereplicated secondary metabolites using PreADMET program version 2.0 showed that flavones (vitexin (1), acacetin (10), diosmetin (18), luteolin, and apigenin (25-26) had low to middle absorption to the blood-brain barrier (BBB), moderate to high human intestinal absorption (HIA), weak to strong plasma protein binding (PPB), moderate skin permeability (SP), middle permeability to heterogeneous human epithelial colorectal adenocarcinoma Caco-2 cells and the Madin-Darby Canine Kidney (MDCK) cell model. Additionally, all flavones inhibited cytochrome $\mathrm{P}_{450}-2 \mathrm{C}_{19}\left(\mathrm{CYP}_{2} \mathrm{C}_{19}\right), \mathrm{CYP}_{2} \mathrm{C}_{9}$, and $\mathrm{CYP}_{3} \mathrm{~A}_{4}$ with no effect on the permeability glycoprotein (Pgp) (Table 2). Toxicity screening results using PreADMET for flavone aglycones showed mutagenicity using the Ames test except for $\mathbf{1}$. Moreover, flavones showed potential rat and rodent carcinogenicity, except for 1, which showed carcinogenicity in rats only. Furthermore, the human Ether-à-go-go-Related Gene (hERG) inhibition is of moderate to high risk (Table 3). Moreover; iridoids (premnoside A and 6-O- $\alpha$-L-(2"-O-trans-caffoyl) rhamnopyranosyl catalpol (2-3), premnoside $\mathrm{C}, \mathrm{D}, \mathrm{H}$, and 6-O- $\alpha$-L-(2"-O-trans-methoxycinnamoyl) rhamnopyranosyl catalpol (5-8), premnoside $\mathrm{G}$ and 6-O- $\alpha$-L-(4"-O-trans-feruolyl) rhamnopyranosyl catalpol (11-12), premnoside E and F (15-16), premnaodoroside A-D and premnoside $\mathrm{D}$ (19-23), premcoryoside 27) and phenylethanoid verbascoside (14) had low absorption to the BBB, except for compounds 11, 15, and 16 which showed moderate absorption, poor HIA, except for compounds 11, 15, and 16 which showed moderate results, weak PPB, poor SP, middle Caco-2, MDCK permeability. Furthermore, all iridoids inhibited Pgp, $\mathrm{CYP}_{2} \mathrm{C}_{19}, \mathrm{CYP}_{2} \mathrm{C}_{9}$, and $\mathrm{CYP}_{3} \mathrm{~A}_{4}$ (Table 2). Toxicity screening results using PreADMET for iridoids and phenylethanoids showed no mutagenicity using the Ames test, except for compounds 19, 21, and 23 which showed positive mutagenicity with the TA100-NA strain and negative mutagenicity with the other strains used. Moreover, iridoids and phenylethanoids showed no potential rat carcinogenicity except against rodents. Also, hERG inhibition was ambiguous, except for compounds 8 and 15-16, which were of high risk (Table 3). The sterols, triterpenes, and fatty acids (daucosterol (4), stigmasterol (9), $\beta$-sitosterol (13), linolenic acid (17), $\beta$-amyrin (24), arjunolic acid (28) had middle to strong absorption to the BBB, high HIA, strong PPB, good SP, middle Caco-2, MDCK permeability; furthermore, all of them inhibited Pgp, $\mathrm{CYP}_{2} \mathrm{C}_{9}$, and $\mathrm{CYP}_{3} \mathrm{~A}_{4}$ (Table 2). Toxicity screening results showed no mutagenicity using the Ames test, except for compound 17. Moreover, these compounds showed potential rat and rodent carcinogenicity, except for compounds 4 and 13, which showed carcinogenicity against rodents only. Furthermore, hERG inhibition is of low to moderate risk (Table 3). 
Table 2. The predicted absorbance, distribution, metabolism, excretion (ADME) properties of the LC-HRESIMS dereplication metabolites of the crude Premna odorata leave extract using the in silico predicts absorption, distribution, metabolism, excretion, and toxicity (PreADMET) method.

\begin{tabular}{|c|c|c|c|c|c|c|c|c|c|c|c|}
\hline No. & РРВ\% & $\begin{array}{c}\text { BBB } \\
\left(C_{\text {brain }} / C_{\text {blood }}\right)\end{array}$ & $\begin{array}{c}\text { SP } \\
\text { (cm/hour) }\end{array}$ & HIA \% & $\begin{array}{c}\text { MDCK } \\
\text { (nm/sec) }\end{array}$ & $\begin{array}{c}\text { Caco-2 } \\
(\mathrm{nm} / \mathrm{sec})\end{array}$ & $\begin{array}{c}\text { Pgp } \\
\text { Inhibition }\end{array}$ & $\begin{array}{l}\mathrm{CYP}_{-2} \mathrm{C}_{19} \\
\text { Inhibition }\end{array}$ & $\begin{array}{c}\mathrm{CYP}_{2} \mathrm{C}_{9} \\
\text { Inhibition }\end{array}$ & $\begin{array}{c}\mathrm{CYP}_{-3} \mathrm{~A}_{4} \\
\text { Inhibition }\end{array}$ & $\begin{array}{l}\mathrm{CYP}_{3} \mathrm{~A}_{4} \\
\text { Substrate }\end{array}$ \\
\hline 1 & 61.323656 & 0.0385273 & -4.61128 & 31.374153 & 0.5424090 & 5.48785 & No & Inhibitor & Inhibitor & Inhibitor & Weak \\
\hline 2 & 54.348583 & 0.0287162 & -3.02912 & 3.7348170 & 0.0447556 & 13.6259 & Inhibitor & Inhibitor & Inhibitor & Inhibitor & Weak \\
\hline 3 & 33.285061 & 0.0298880 & -4.70662 & 3.3153240 & 0.1538230 & 11.0644 & Inhibitor & Inhibitor & Inhibitor & Inhibitor & Weak \\
\hline 4 & 100.000000 & 5.3038700 & -2.20420 & 90.027561 & 0.1220710 & 25.2333 & Inhibitor & No & Inhibitor & Inhibitor & Substrate \\
\hline 5 & 54.577268 & 0.0305549 & -2.97228 & 8.4947690 & 0.0455697 & 14.1947 & Inhibitor & Inhibitor & Inhibitor & Inhibitor & Weak \\
\hline 6 & 56.739888 & 0.0342009 & -2.91786 & 19.057599 & 0.0454732 & 14.7567 & Inhibitor & Inhibitor & Inhibitor & Inhibitor & Substrate \\
\hline 7 & 48.364678 & 0.0424033 & -2.96634 & 16.156072 & 0.0454091 & 14.0366 & Inhibitor & Inhibitor & Inhibitor & Inhibitor & Weak \\
\hline 8 & 33.832287 & 0.06277950 & -4.6442 & 13.170559 & 0.1289870 & 12.3956 & Inhibitor & Inhibitor & Inhibitor & Inhibitor & Weak \\
\hline 9 & 100.000000 & 19.8938000 & -0.717667 & 100.00000 & 3.783450 & 52.3376 & Inhibitor & No & Inhibitor & Inhibitor & Substrate \\
\hline 10 & 90.917451 & 0.15030900 & -3.36001 & 93.042708 & 20.230800 & 12.7923 & No & Inhibitor & Inhibitor & Inhibitor & No \\
\hline 11 & 53.912360 & 0.1319930 & -2.9222 & 52.345314 & 0.0449026 & 15.3124 & Inhibitor & Inhibitor & Inhibitor & Inhibitor & Weak \\
\hline 12 & 32.612262 & 0.0411953 & -4.70477 & 5.9983830 & 0.1105100 & 9.11617 & Inhibitor & Inhibitor & Inhibitor & Inhibitor & Weak \\
\hline 13 & 100.000000 & 19.8883000 & -0.593439 & 100.00000 & 8.8571900 & 52.3734 & Inhibitor & No & Inhibitor & Inhibitor & Substrate \\
\hline 14 & 64.288492 & 0.03167600 & -3.5116 & 7.6711810 & 0.0450549 & 11.1087 & Inhibitor & Inhibitor & Inhibitor & Inhibitor & Weak \\
\hline 15 & 54.629780 & 0.1252660 & -2.92245 & 52.345571 & 0.0451432 & 15.4511 & Inhibitor & Inhibitor & Inhibitor & Inhibitor & Weak \\
\hline 16 & 53.912360 & 0.1319930 & -2.9222 & 52.345314 & 0.0449026 & 15.3124 & Inhibitor & Inhibitor & Inhibitor & Inhibitor & Weak \\
\hline 17 & 100.000000 & 6.16921000 & -0.538273 & 98.273607 & 74.789700 & 27.9738 & Inhibitor & Inhibitor & Inhibitor & Inhibitor & No \\
\hline 18 & 90.160128 & 0.20108600 & -4.13473 & 88.188263 & 23.853100 & 7.02526 & No & Inhibitor & Inhibitor & Inhibitor & No \\
\hline 19 & 34.413157 & 0.0284513 & -3.29001 & 1.9433930 & 0.2328650 & 16.3835 & Inhibitor & Inhibitor & Inhibitor & Inhibitor & Substrate \\
\hline 20 & 40.461576 & 0.0298628 & -3.70182 & 4.3580790 & 0.0841395 & 17.2768 & Inhibitor & Inhibitor & Inhibitor & Inhibitor & Substrate \\
\hline 21 & 41.088270 & 0.0302347 & -3.26196 & 5.1422870 & 0.1599090 & 15.3574 & Inhibitor & Inhibitor & Inhibitor & Inhibitor & Substrate \\
\hline 22 & 45.368220 & 0.0328157 & -3.02594 & 7.1270550 & 0.0447377 & 12.7477 & Inhibitor & Inhibitor & Inhibitor & Inhibitor & Weak \\
\hline 23 & 34.183542 & 0.0283962 & -3.80436 & 2.2958830 & 0.291627 & 17.4161 & Inhibitor & Inhibitor & Inhibitor & Inhibitor & Substrate \\
\hline 24 & 100.000000 & 21.2500000 & -2.22251 & 100.00000 & 0.1749200 & 46.7500 & Inhibitor & No & Inhibitor & Inhibitor & Substrate \\
\hline 25 & 99.717233 & 0.36758200 & -4.28017 & 79.427233 & 36.520500 & 4.53973 & No & Inhibitor & Inhibitor & Inhibitor & No \\
\hline 26 & 97.253409 & 0.56511300 & -4.14570 & 88.122839 & 44.302000 & 10.5468 & No & Inhibitor & Inhibitor & Inhibitor & No \\
\hline 27 & 37.405289 & 0.0273879 & -2.50822 & 0.3453560 & 0.0434853 & 11.7965 & Inhibitor & Inhibitor & Inhibitor & Inhibitor & Substrate \\
\hline 28 & 97.049829 & 0.58860800 & -3.57106 & 91.233319 & 0.0434480 & 20.9815 & Inhibitor & No & Inhibitor & Inhibitor & Substrate \\
\hline
\end{tabular}

PPB: plasma protein binding; BBB: blood-brain barrier; SP: skin permeability; HIA: human intestinal absorption; MDCK: Madin-Darby Canine Kidney; Pgp: permeability glycoprotein; and CYP: cytochrome P. In PPB, the drug is considered; chemicals are strongly PPB at $>90 \%$ PPB and weakly at $<90 \%$. In the BBB, the drug is considered to have high absorption to the CNS at $>2.0 \mathrm{BB}$ (Cbrain/Cblood), middle absorption to the CNS at 2.0 0.1 BB (Cbrain/Cblood), and low absorption to the CNS at $<0.1$ BB (Cbrain/Cblood). For SP, PreADMET predicts in vitro skin permeability and the result value is given as $\log \mathrm{Kp} . \mathrm{Kp}(\mathrm{cm} / \mathrm{hour})$ is defined as follows: $\mathrm{KP}=\frac{\mathrm{km} \times \mathrm{D}}{\mathrm{h}}$, where $K m$ is the coefficient of distribution between the stratum corneum and the vehicle, $D$ is the average diffusion coefficient $\left(\mathrm{cm}^{2} / \mathrm{h}\right)$, and $h$ is the thickness of skin $(\mathrm{cm})$. In HIA, the drug is considered a poorly absorbed compound at $0 \sim 20 \%$, a moderately absorbed compound at $20 \sim 70 \%$, and a well-absorbed compound at 70 100\%. In the Caco-2 cell permeability and the MDCK cell model, the drug could generally belong to one of three categories: low permeability $<4 \mathrm{P}_{\mathrm{Caco}-2}(\mathrm{~nm} / \mathrm{sec})$, moderate permeability $4 \sim 70 \mathrm{P}_{\mathrm{Caco}-2}(\mathrm{~nm} / \mathrm{sec})$, and high permeability $>70 \mathrm{P}_{\mathrm{Caco}-2}$ (nm/sec). Pgp is an important protein of the cell membrane that pumps many foreign substances out of cells, and it likely evolved as a defense mechanism against harmful substances. Cytochrome $P_{450}-2 C_{19}\left(C Y P_{2} C_{19}\right), C Y P_{2} C_{9}$, and $\mathrm{CYP}_{3} \mathrm{~A}_{4}$, are important cytochrome $\mathrm{P}_{450}$ enzymes with a major role in the oxidation of both xenobiotic and endogenous compounds. 
Table 3. Toxicity profile of the LC-HRESIMS dereplication metabolites of Premna odorata leaves crude extract using in silico predicts absorption, distribution, metabolism, excretion, and toxicity (PreADMET) method.

\begin{tabular}{|c|c|c|c|c|c|c|c|c|}
\hline No. & Ames Test & TA100-10RLI & TA100-NA & TA1535-10RLI & TA1535-NA & Carcinogenic for Mice & Carcinogenic for Rats & HERG Inhibition \\
\hline 1 & Non-mutagenic & - & - & - & - & + & - & High risk \\
\hline 2 & Non-mutagenic & - & - & - & - & + & - & Ambiguous \\
\hline 3 & Non-mutagenic & - & - & - & - & + & - & Ambiguous \\
\hline 4 & Non-mutagenic & - & - & - & - & + & - & Low risk \\
\hline 5 & Non-mutagenic & - & - & - & - & + & - & Ambiguous \\
\hline 6 & Non-mutagenic & - & - & - & - & + & - & Ambiguous \\
\hline 7 & Non-mutagenic & - & - & - & - & + & - & Ambiguous \\
\hline 8 & Non-mutagenic & - & - & - & - & + & - & High risk \\
\hline 9 & Non-mutagenic & - & - & - & - & + & + & Low risk \\
\hline 10 & Mutagenic & + & + & - & - & + & + & Moderate risk \\
\hline 11 & Non-mutagenic & - & - & - & - & + & - & Ambiguous \\
\hline 12 & Non-mutagenic & - & - & - & - & + & - & Ambiguous \\
\hline 13 & Non-mutagenic & - & - & - & - & + & - & Low risk \\
\hline 14 & Non-mutagenic & - & - & - & - & + & - & Ambiguous \\
\hline 15 & Non-mutagenic & - & - & - & - & + & - & High risk \\
\hline 16 & Non-mutagenic & - & - & - & - & + & - & High risk \\
\hline 17 & Mutagenic & - & - & - & + & + & + & Moderate risk \\
\hline 18 & Mutagenic & - & + & - & - & + & + & Moderate risk \\
\hline 19 & Mutagenic & - & + & - & - & + & - & Ambiguous \\
\hline 20 & Non-mutagenic & - & - & - & - & + & - & Ambiguous \\
\hline 21 & Mutagenic & - & + & - & - & + & - & Ambiguous \\
\hline 22 & Non-mutagenic & - & - & - & - & + & - & Ambiguous \\
\hline 23 & Mutagenic & - & + & - & - & + & - & Ambiguous \\
\hline 24 & Non-mutagenic & - & - & - & - & + & + & Low risk \\
\hline 25 & Mutagenic & - & + & - & - & + & + & Moderate risk \\
\hline 26 & Mutagenic & + & + & - & - & + & + & Moderate risk \\
\hline 27 & Non-mutagenic & - & - & - & - & + & - & Ambiguous \\
\hline 28 & Non-mutagenic & - & - & - & - & + & + & Low risk \\
\hline
\end{tabular}


HERG: human Ether-à-go-go-Related Gene. The Ames test is a simple method of testing mutagenicity of a compound. PreADMET predicts toxicity for TA98, TA100, and TA1535, which are often used in the Ames test. The prediction result is positive or negative. Rodent carcinogenicity is a toxicity that causes cancer in the body. PreADMET predicts the result from its model, which is built upon the data of the National Toxicology Program (NTP) and the United States Food and Drug Administration (US FDA), which are the results of the 2-year-long in vivo carcinogenicity tests of mice and rats. Negative prediction indicates clear evidence of carcinogenic activity, and positive prediction shows no evidence of carcinogenic activity. The hERG is a gene that codes for a protein known as $K_{v} 11.1$, the alpha subunit of a potassium ion channel. This ion channel is best known for its contribution to the electrical activity of the heart. The hERG channel mediates the repolarizing $\mathrm{I}_{\mathrm{Kr}}$ current in the cardiac action potential, which helps coordinate the heart's beating.

\subsection{In Vitro Measurement of Total Reactive Oxygen Species (ROS)}

Various Premna odorata extracts (crude, defatted crude, and n-hex) were screened for their ability to scavenge the ROS in the Hep G2 human liver cancer cell line at $100 \mu \mathrm{L}$ using the Reactive Oxygen Species Assay (Beyotime Institute of Biotechnology) (Figure 2). The results showed that the treatment with all the extracts significantly decreases the Hep G2 ROS content, reflecting activities of their antioxidants. Silymarin with defined antioxidant activity was used as a standard reference drug at a $100 \mu \mathrm{L}$ dose.

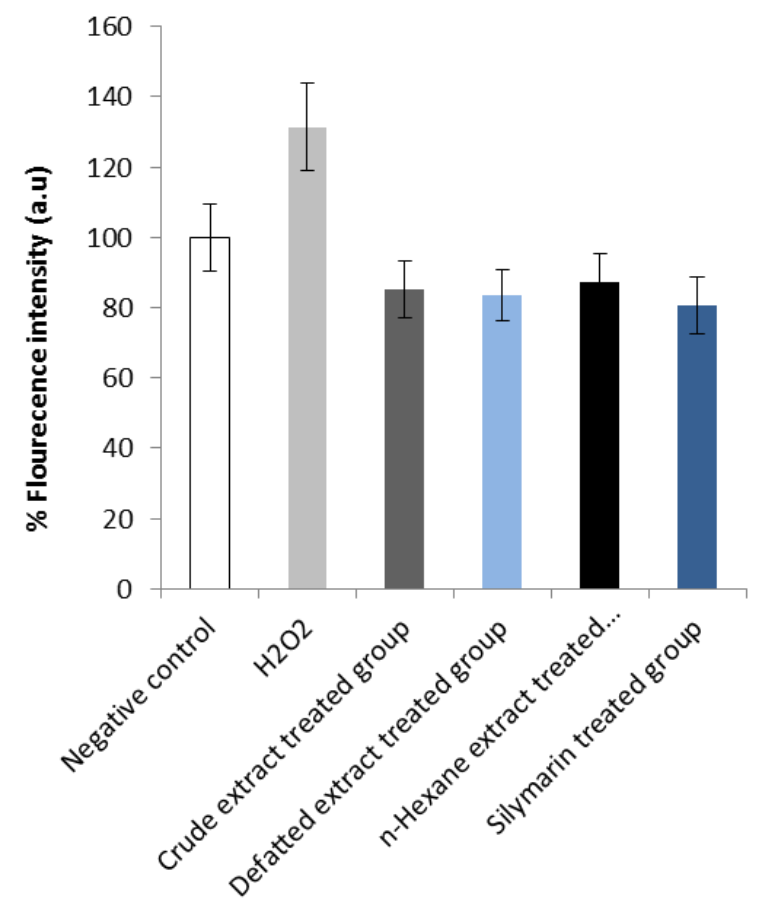

Figure 2. Reactive oxygen species (ROS) induction by $\mathrm{H}_{2} \mathrm{O}_{2}$ in the Hep G2 human liver cancer cell line: scavenging effects of various Premna odorata extracts. The cells were treated with $100 \mu \mathrm{L}$ and evaluated for ROS production as described in the Materials and Methods. The data (means \pm SD) are representative of three independent experiments. Significant difference at $p<0.05$ versus $\mathrm{H}_{2} \mathrm{O}_{2}$.

\subsection{Acute Toxicity}

In this study, the acute toxicity test of the crude, defatted crude, and n-hex extracts showed no signs of toxicity up to $5 \mathrm{~g} / \mathrm{kg}$ body weight (b.w.); they were considered safe. Therefore, all extracts were investigated at a dose of $1 / 10(500 \mathrm{mg} / \mathrm{kg}$ b.w.) in the alcohol-inflamed liver of female Wistar albino rats. 


\subsection{Potential Effects of Premna odorata Extracts in Liver Function Tests}

In response to the alcohol-inflamed liver, bilirubin, AST, ALT, and ALP showed a significant increase in their serum levels with the percentage reaching $65.88 \%, 108.53 \%, 33.05 \%$, and $34.04 \%$, respectively, when compared to the negative control group (Table 4). Treatment of alcohol-inflamed liver rats with crude, defatted crude, $n$-hex extracts showed a significant decrease in the bilirubin, AST, ALT, and ALP levels in all treated groups when compared to the silymarin positive control group. The crude leave extract showed the highest percentage of improvement for AST (143.23\%) and ALP $(48.47 \%)$. While bilirubin showed a significant improvement upon treatment with crude and n-hex extracts (58.11\%), the defatted crude extract showed the best improvement of the ALT level (66.68\%) in all treated groups (Table 4).

\subsection{Potential Effects of Premna odorata Extracts on Oxidative Stress Markers, and Antioxidant}

In response to the alcohol-inflamed liver state, the MDA level showed a significant increase (42.97\%) when compared to the negative control group. The GSH and TAC had a significant decrease of $27.42 \%$ and $38.46 \%$, respectively (Table 4 ). Treatment of alcohol-inflamed liver rats with crude, defatted crude, n-hex extracts showed a significant increase in the GSH and TAC levels in all treated groups compared to the silymarin positive control group (Table 4). Defatted crude and n-hex extracts showed the highest percentage of improvement for the GSH (50.32\%) and TAC (42.30\%). MDA showed a significant decrease in all treated groups, whereas the crude extract showed the best amelioration $-71.07 \%$ (Table 4$)$.

\subsection{Potential Effects of Premna odorata Extracts on Inflammatory Markers and Adhesion Molecules}

In response to the alcohol-inflamed liver state, CRP, TNF- $\alpha$, ICAM-1, and VCAM-1 parameters showed a significant increase in their levels, 86.96\%, 98.49\%, 114.54\%, and 51.72\%, respectively, when compared to the negative control group (Table 4). Treatment of alcohol-inflamed liver rats with crude, defatted crude, n-hex extracts showed a significant decrease in CRP, TNF- $\alpha$, VCAM- 1 , and ICAM-1 when compared to the silymarin positive control group (Table 2). The n-hex fraction recorded the highest percentage of improvement for CRP $(86.20 \%)$ and ICAM-1 (96.36\%). The defatted crude extract showed the highest percentage of amelioration for TNF- $\alpha(102.56 \%)$. VCAM-1 was improved upon treatment with defatted crude and n-hex extracts (41.37\%) (Table 4).

\subsection{Histopathological Investigation of Liver}

The histological investigation of liver sections supported the biochemical results (Figure 3). Liver sections for the control rat group showed normal lobular architecture and normal hepatic cells with a well-preserved cytoplasm and a well-defined nucleus (Figure 3A). Alcohol-inflamed liver (positive control) showed a necrobiotic change of the hepatocytes, including congestion of the central vein and hepatic sinusoids, cytoplasmic vacuolization of hepatocytes, portal edema, and focal hepatic necrosis associated with inflammatory cell infiltration (Figure 3B-D). Treatment of alcohol-inflamed liver rats with Premna odorata extracts (crude, defatted crude, and n-hex) (Figure 3E-I) showed positive results for all extracts in which focal tubular necrosis associated with inflammatory cell infiltration was minimum, where the crude extract was the most active followed by the defatted crude and the n-hex extracts. The slight congestion of hepatic sinusoids was also observed. The silymarin-treated group (Figure 3K-L) showed a slightly hydropic regeneration of hepatocytes and focal hepatic hemorrhage. 
Table 4. Results of the liver function, oxidative stress marker, antioxidant, inflammatory marker, and adhesion molecule tests measuring the activity of the Premna odorata crude, defatted, and n-hex extracts induced in alcohol-inflamed liver female Wistar albino rats according to Keegan (2013) [23] using a dose of 500 mg/kg b.w. for thirty days who were then euthanized (silymarin was used as a reference drug using a $200 \mathrm{mg} / \mathrm{kg}$ b.w. dose).

\begin{tabular}{|c|c|c|c|c|c|c|c|}
\hline \multirow[b]{2}{*}{ Parameters } & & \multicolumn{6}{|c|}{ Groups } \\
\hline & & 1 & 2 & 3 & 4 & 5 & 6 \\
\hline \multirow{3}{*}{$\begin{array}{l}\text { Bilirubin } \\
\text { (mg/dl) }\end{array}$} & Mean \pm SD & $0.85 \pm 0.05^{b}$ & $1.41 \pm 0.18^{a}$ & $0.916 \pm 0.07^{b}$ & $0.95 \pm 0.05^{b}$ & $0.916 \pm 0.076^{b}$ & $0.8 \pm 0.05^{b}$ \\
\hline & $\%$ change & & 65.88 & 7.76 & 11.76 & 7.76 & 5.88 \\
\hline & $\%$ improvement & & & 58.11 & 54.11 & 58.11 & 71.76 \\
\hline \multirow{3}{*}{$\begin{array}{l}\text { AST } \\
(\mathrm{U} / \mathrm{I})\end{array}$} & Mean \pm SD & $39.00 \pm 7.81^{b}$ & $81.33 \pm 21.45^{\mathrm{a}}$ & $25.47 \pm 4.50^{\mathrm{d}}$ & $28.33 \pm 1.53^{\mathrm{cd}}$ & $32.33 \pm 2.08^{b c}$ & $31.47 \pm 3.51 \mathrm{bcd}$ \\
\hline & $\%$ change & & 108.53 & 34.20 & 27.30 & 17.10 & 19.31 \\
\hline & $\%$ improvement & & & 143.23 & 133.23 & 125.64 & 127.84 \\
\hline \multirow{3}{*}{$\begin{array}{l}\text { ALT } \\
(\mathrm{U} / \mathrm{I})\end{array}$} & Mean \pm SD & $108.47 \pm 18.85^{b}$ & $144.33 \pm 25.1^{\mathrm{a}}$ & $77.33 \pm 4.42^{b c}$ & $72.00 \pm 2.00 \mathrm{bc}$ & $92.47 \pm 16.28^{b}$ & $93.33 \pm 5.77^{b}$ \\
\hline & $\%$ change & & 33.05 & 28.71 & 33.62 & 14.75 & 13.96 \\
\hline & $\%$ improvement & & & 61.76 & 66.68 & 47.81 & 47.02 \\
\hline \multirow{3}{*}{$\begin{array}{l}\text { ALP } \\
(\mathrm{IU} / \mathrm{L})\end{array}$} & Mean \pm SD & $173.33 \pm 29.29 b c$ & $232.33 \pm 2.51^{\mathrm{a}}$ & $148.33 \pm 10.40 \mathrm{bc}$ & $181.47 \pm 7.44^{b}$ & $185 \pm 18.02^{b}$ & $141.47 \pm 2.51^{\mathrm{c}}$ \\
\hline & $\%$ change & & 34.04 & 14.42 & 4.69 & 6.73 & 18.27 \\
\hline & \% improvement & & & 48.47 & 29.32 & 27.29 & 52.42 \\
\hline \multirow{3}{*}{$\begin{array}{c}\text { MDA } \\
(\mathrm{mmol} / \mathrm{l})\end{array}$} & Mean \pm SD & $2818.85 \pm 200.5^{c}$ & $4,029.85 \pm 200.5^{a}$ & $2,026.33 \pm 52.50^{d}$ & $2,121.47 \pm 91.76^{d}$ & $2,248.00 \pm 141.24^{d}$ & $3,250.47 \pm 416.41^{b}$ \\
\hline & $\%$ change & & 42.97 & 28.11 & 24.73 & 20.22 & 15.33 \\
\hline & $\%$ improvement & & & 71.07 & 67.21 & 63.20 & 27.60 \\
\hline \multirow{3}{*}{$\begin{array}{c}\text { GSH } \\
(\mathrm{mg} / \mathrm{g} \text { tissue used })\end{array}$} & Mean \pm SD & $412.86 \pm 56.94 \mathrm{bc}$ & $299.16 \pm 54.98^{d}$ & $491.91 \pm 27.56^{c}$ & $506.88 \pm 86.32^{b}$ & $495.46 \pm 28.99 \mathrm{ab}$ & $411.29 \pm 77.11^{b c}$ \\
\hline & $\%$ change & & 27.42 & 19.15 & 22.77 & 20.26 & 0.24 \\
\hline & \% improvement & & & 46.60 & 50.32 & 47.57 & 27.18 \\
\hline \multirow{3}{*}{$\begin{array}{c}\text { TAC } \\
(\mathrm{mmol} / \mathrm{l})\end{array}$} & Mean \pm SD & $0.26 \pm 0.02^{a}$ & $0.16 \pm 0.02^{b}$ & $0.26 \pm 0.02^{a}$ & $0.26 \pm 0.02^{a}$ & $0.27 \pm 0.03^{a}$ & $0.29 \pm 0.02^{a}$ \\
\hline & $\%$ change & & 38.46 & 0 & 0 & 3.84 & 11.53 \\
\hline & \% improvement & & & 38.46 & 38.46 & 42.30 & 50.00 \\
\hline
\end{tabular}


Table 4. Cont

\begin{tabular}{|c|c|c|c|c|c|c|c|}
\hline \multirow[b]{2}{*}{ Parameters } & & \multicolumn{6}{|c|}{ Groups } \\
\hline & & 1 & 2 & 3 & 4 & 5 & 6 \\
\hline \multirow{3}{*}{$\begin{array}{c}\text { CRP } \\
(\mathrm{ng} / \mathrm{mL})\end{array}$} & Mean \pm SD & $29.30 \pm 2.01^{b}$ & $54.58 \pm 2.18^{a}$ & $32.47 \pm 2.51^{b}$ & $33.33 \pm 1.52^{b}$ & $29.03 \pm 2.74^{b}$ & $31.20 \pm 1.38^{b}$ \\
\hline & $\%$ change & & 86.96 & 10.34 & 13.79 & 1.02 & 6.48 \\
\hline & $\%$ improvement & & & 75.86 & 72.40 & 86.20 & 80.34 \\
\hline \multirow{3}{*}{$\begin{array}{l}\text { TNF- } \alpha \\
(\mathrm{pg} / \mathrm{mL})\end{array}$} & Mean \pm SD & $39.33 \pm 2.47^{b c}$ & $73.03 \pm 2.45^{a}$ & $43.47 \pm 2.76^{b c}$ & $33.47 \pm 1.53^{c}$ & $41.47 \pm 2.39 \mathrm{bc}$ & $52.41 \pm 1.45^{b}$ \\
\hline & $\%$ change & & 98.49 & 10.25 & 15.38 & 5.12 & 33.74 \\
\hline & $\%$ improvement & & & 76.92 & 102.56 & 82.76 & 53.84 \\
\hline \multirow{3}{*}{$\begin{array}{l}\text { ICAM-1 } \\
(\mu \mathrm{g} / \mathrm{mL})\end{array}$} & Mean \pm SD & $5.53 \pm 0.47^{c}$ & $11.81 \pm 1.22^{a}$ & $7.46 \pm 1.41^{b}$ & $6.83 \pm 0.77^{b c}$ & $6.49 \pm 0.41^{b c}$ & $6.43 \pm 0.56^{b c}$ \\
\hline & $\%$ change & & 114.54 & 36.36 & 23.50 & 18.18 & 16.30 \\
\hline & $\%$ improvement & & & 78.18 & 90.05 & 96.20 & 98.18 \\
\hline \multirow{3}{*}{$\begin{array}{l}\text { VCAM-1 } \\
(\mu \mathrm{g} / \mathrm{mL})\end{array}$} & Mean \pm SD & $2.92 \pm 0.12^{b}$ & $4.46 \pm 1.30^{a}$ & $3.40 \pm 0.20^{b}$ & $3.29 \pm 0.23^{b}$ & $3.22 \pm 0.58^{b}$ & $2.96 \pm 0.11^{b}$ \\
\hline & $\%$ change & & 51.72 & 17.24 & 13.79 & 13.79 & 3.45 \\
\hline & $\%$ improvement & & & 37.93 & 41.37 & 41.37 & 51.72 \\
\hline
\end{tabular}

Group 1: negative control group; group 2: alcohol-inflamed liver (positive control group); group 3: crude extract-treated group; group 4: defatted crude extract-treated group; group 5: n-hexane extract-treated group; group 6: silymarin-treated group; AST: aspartate aminotransferase; ALT: alanine aminotransferase; ALP: alkaline phosphatase; MDA: malondialdehyde; GSH: glutathione; TAC: total antioxidant capacity; CRP: C-reactive protein; TNF- $\alpha$ : tumor necrosis factor- $\alpha$; ICAM-1: intercellular adhesion molecule-1; VCAM-1: vascular cell adhesion molecule-1.Pooled data presented as the means \pm standard deviation (SD) for ten rats in each group. The differences between various treatment groups determined by the ANOVA molecule-1.Pooled data presented as the means \pm standard deviation (SD) for ten rats in each group. The differences between various treatment groups determined by the ANOVA
followed by the Dunnett's test using PASW Statistics ${ }^{\circledR}$ version 18 (Quarry Bay, Hong Kong), ${ }^{\text {a }}{ }^{\mathrm{d}}$ : Means with different letters in the same row differs significantly ( $p \leq 0.05$ ), where an unshared letter is considered significant at $p \leq 0.05$. 

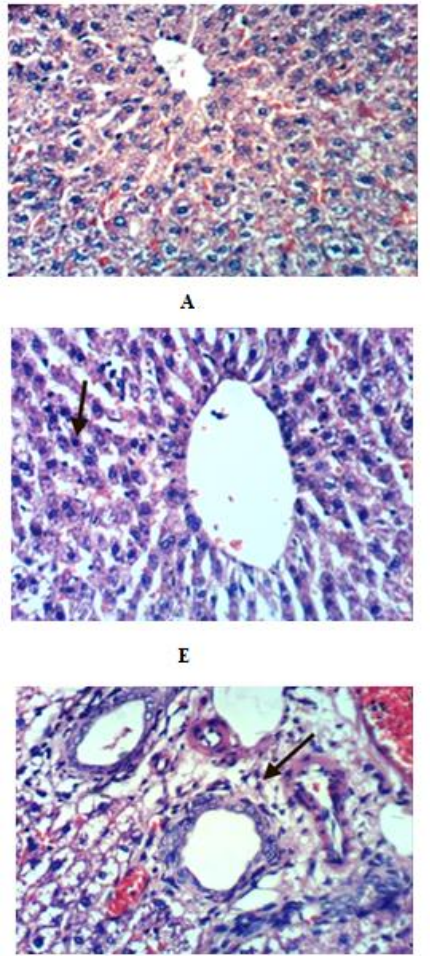
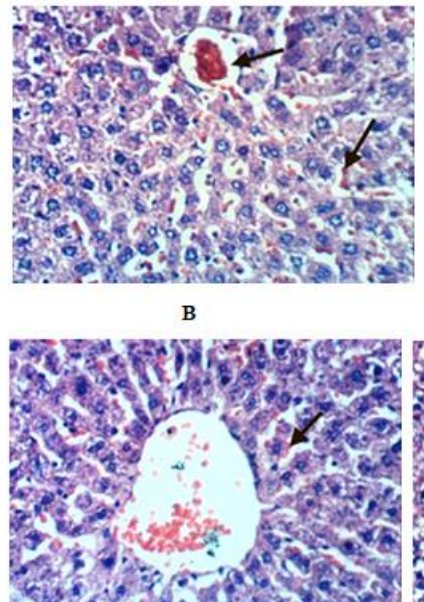

$\mathbf{F}$

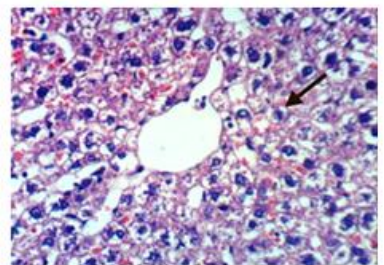

$\mathbf{J}$

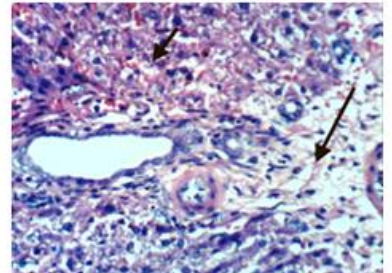

c
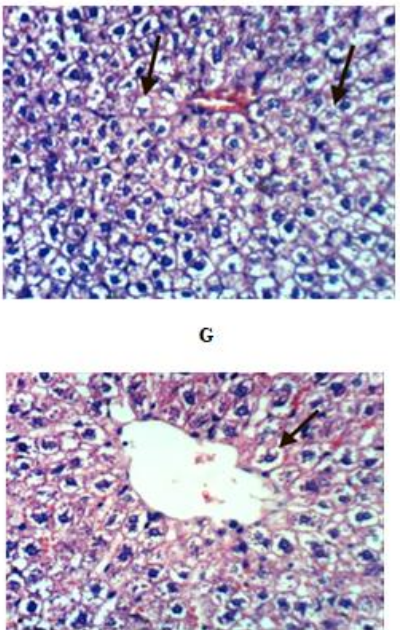
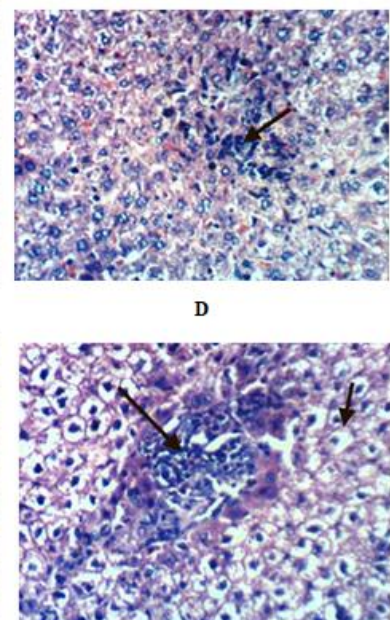

н

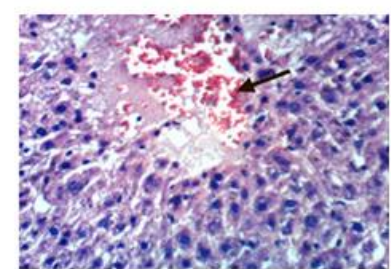

Figure 3. Histopathological results of the activity for Premna odorata extracts (crude, defatted, and n-hexane) and silymarin in alcohol-inflamed liver female Wistar albino rats using a dose of 500 and $200 \mathrm{mg} / \mathrm{kg}$ b.w., respectively (H and E X 400). (A) The liver of a rat from group 1 (negative control) showing the negative histological structure of a hepatic lobule. (B) The liver of a rat from group 2 (positive control) showing congestion of the central vein and hepatic sinusoids. (C) The liver of a rat from group 2 showing cytoplasmic vacuolization of hepatocytes and a portal edema. (D) The liver of a rat from group 2 showing focal hepatic necrosis associated with inflammatory cell infiltration. (E) The liver of a rat from group 3 (crude extract-treated group) showing necrosis of sporadic hepatocytes. (F) The liver of a rat from group 3 showing slight congestion of hepatic sinusoids. (G) The liver of a rat from group 4 (defatted extract-treated group) showing slightly hydropic degeneration of hepatocytes. (H) The liver of a rat from group 4 showing hydropic degeneration of hepatocytes and focal hepatic necrosis associated with inflammatory cell infiltration. (I) The liver of a rat from group 5 (n-hexane-treated group) showing a slightly portal edema. (J) The liver of a rat from group 5 showing slightly hydropic degeneration of hepatocytes. (K) The liver of a rat from group 6 (silymarin-treated group) showing slightly hydropic degeneration of hepatocytes. (L) The liver of a rat from group 6 showing slightly focal hepatic hemorrhage. 


\section{Discussion}

Metabolic profiling of Premna odorata dereplicated 28 metabolites from the various fractions of the crude leave extract. The identified metabolites belonged to various chemical classes, including iridoids (monoterpenes), triterpenes, flavones, and phenylethanoids. According to literature, pharmacokinetic parameters of compounds, such as absorption, distribution, metabolism, excretion, and toxicity (ADMET), are important in order to determine the potential success of a compound for therapeutic use. Some important chemical descriptors correlate well with ADMET properties, for instance, HIA as a primary determinant of oral absorption of a fraction. The distribution of each compound in the human body depends on many factors, such as permeability of the BBB, Caco-2, MDCK, SP, and PPB. Similarly, the metabolism and excretion of most drugs also depend on many factors, like $\mathrm{CYP}_{2} \mathrm{C}_{19}, \mathrm{CYP}_{2} \mathrm{C}_{9}$, $\mathrm{CYP}_{3} \mathrm{~A}_{4}$, and Pgp. In silico predicted ADMET profiling of the dereplicated secondary metabolites present in Premna odorata leaves showed that flavones (vitexin (1), acacetin (10), diosmetin (18), luteolin, and apigenin (25-26) had low to middle absorption to the BBB, moderate to high HIA, weak to strong PPB, moderate SP, and middle Caco-2 and MDCK permeability. Furthermore, all flavones inhibited $\mathrm{CYP}_{2} \mathrm{C}_{19}, \mathrm{CYP}_{2} \mathrm{C}_{9}$, and $\mathrm{CYP}_{3} \mathrm{~A}_{4}$ and had no significant effect on Pgp (Table 2). Toxicity screening results from PreADMET for the flavone aglycones showed mutagenicity using the Ames test, except for 1. Moreover, all flavones showed potential rat and rodent carcinogenicity, except for 1, which only showed carcinogenicity against rats. Furthermore, a moderate to high risk of hERG inhibition was predicted (Table 3). The iridoids (premnoside A and 6-O- $\alpha$-L-(2"-O-trans-caffoyl) rhamnopyranosyl catalpol (2-3), premnoside $\mathrm{C}, \mathrm{D}, \mathrm{H}$, and 6-O- $\alpha$-L-(2"-O-trans-methoxycinnamoyl) rhamnopyranosyl catalpol (5-8), premnoside $\mathrm{G}$ and 6-O- $\alpha$-L-(4"-O-trans-feruolyl) rhamnopyranosyl catalpol (11-12), premnoside E, F (15-16), premnaodoroside A-D and premnoside D (19-23), premcoryoside (27) and phenylethanoid verbascoside (14) had low absorption to the BBB, except for 11, 15, and 16, which showed moderate absorption, poor HIA, except for 11, 15, 16, which showed moderate results, weak PPB, poor SP, and moderate Caco-2 and MDCK permeability. Furthermore, all iridoids inhibited Pgp, $\mathrm{CYP}_{2} \mathrm{C}_{19}, \mathrm{CYP}_{2} \mathrm{C}_{9}$, and $\mathrm{CYP}_{3} \mathrm{~A}_{4}$ (Table 2). Toxicity screening results from PreADMET for the iridoids showed no mutagenicity using the Ames mutagenicity test, except for 19, 21, and 23, which showed positive mutagenicity for the TA100-NA strain and negative mutagenicity for the other strains used. Moreover, iridoids and phenylethanoids showed no potential rat carcinogenicity except against rodents. Furthermore, hERG inhibition was ambiguous, except for 8, and 15-16 were of high risk (Table 3). The sterols, triterpenes, and fatty acids (daucosterol (4), stigmasterol (9), $\beta$-sitosterol (13), linolenic acid (17), $\beta$-amyrin (24), arjunolic acid (28)) had moderate to strong absorption to the $\mathrm{BBB}$, high HIA, strong PPB, good SP, middle Caco-2, MDCK permeability, and all inhibited Pgp, $\mathrm{CYP}_{2} \mathrm{C}_{9}$, and $\mathrm{CYP}_{3} \mathrm{~A}_{4}$ (Table 2). Toxicity screening results showed no mutagenicity using the Ames mutagenicity test, except for 17. Moreover, these compounds showed potential rat and rodent carcinogenicity, except for 4 and 13, which showed mutagenicity against rodents only. Furthermore, hERG inhibition is of low to moderate risk (Table 3). The results of in silico screening highlight that Premna odorata metabolites theoretically are potentially highly bioactive. These features are reflected by their low plasma concentrations due to their extensive cellular uptake [24]. Tight regulation of the compound plasma concentrations was accomplished through binding to serum albumin [25], which lowers plasma concentrations of unbound bioactive compounds, while offering a storage system for delayed release into the plasma. In addition, albumin-bound compounds are more stable against oxygen-dependent degradation, resulting in prolongation of their biological availability and further extension of their plasma's half-life. This response would protect target tissues from high-level uptake of compounds, which might trigger a toxic reaction in cells [25]. Indeed, prolonged release of these compounds from plasma proteins would ensure a more constant rate of cellular uptake [26]. On the other hand, the ADME properties of these compounds increased their toxicity and carcinogenicity. Generally, higher lipophilicity of compounds leads to increased metabolism and poor absorption along with an increased probability of binding to undesired hydrophobic macromolecules, thereby increasing the potential for toxicity [27] (Tables 2 and 3). 
Literature indicated there is a relationship between liver disease and heavy alcohol consumption, as liver is the primary site of alcohol metabolism [28]. There are two pathways for alcohol metabolism in the liver [29]. The first is the alcohol dehydrogenase (ADH) pathway, which converts alcohol through oxidation processes to acetaldehyde which was found to be highly toxic to the body even in low concentrations. The second, the microsomal enzyme oxidizing system (MEOS) pathway that oxidizes alcohol to acetaldehyde by cytochrome $\mathrm{P}_{450} 2 \mathrm{E}_{1}$, or $\mathrm{CYP}_{2} \mathrm{E}_{1}$. In the latter, activation increases ROS production. Unfortunately, an increase in alcohol consumption also activates the MEOS pathway, resulting in the increased ROS production [29]. Normally, ROS are quickly scavenged by natural protective antioxidants (GSH, GSH-Px, vitamins A and E), but chronic alcohol consumption diminishes antioxidant levels and renders liver cells more susceptible to free radical-induced injuries [5]. This destructive interaction with vital cell constituents potentially causes cell death, resulting in the sequential degradation of cell membranes by a lipid peroxidation process [5]. Consequently, chronic alcohol consumption causes severe liver cell inflammation [5], which results in activation of the NF- $\kappa$ B pathway, increasing the production of TNF- $\alpha$, CRP, IL-1, IL-6 and IL-12, VCAM-1 and ICAM-1, ROS, iNOS, and COX-II $[1,3]$. These molecules together elicit the production of PGE 2 , chemokines, and various co-stimulatory molecules, which play important roles in the pathogenesis of liver cell inflammation [1].

Metabolic profiling of the crude Premna odorata leave extract dereplicated various anti-inflammatory and antioxidants compounds. Vitexin (1) showed significant inhibition to TNF- $\alpha$ and NO [30], acacetin (10) and apigenin (26) inhibited expression of ICAM-1, VCAM-1, and selective inhibition of prostaglandin synthesis and IL-6, 8 production [23,31]. Diosmetin (10) prevented the generation of intracellular ROS and the formation of MDA, increased the effects of the intracellular antioxidant enzymes superoxide dismutase (SOD), catalse (CAT), and GH-Px, and suppressed the iNOS activity [32]. Diosmetin also exerted an anti-inflammatory effect by reducing NO production and TNF- $\alpha$ release, reduced the enzyme activities of COX-II and $\mathrm{PGE}_{2}$, and blocked the NF- $\mathrm{KB}$ signaling pathway [32]. Luteolin (25) also blocked the NF- $\mathrm{B}$ signaling pathway and VCAM-1 expression [33]. Moreover, the crude Premna odorata leave extract contained iridoids which mainly acylated with aromatic acids (coumaric, P-methoxy cinnamic, caffeic, or ferulic) (Table 1, Figure 1), and aliphatic dimer iridoids (2-3, 5-8, 11-12, 15-16, 19-23, 27), both of which prevented the generation of ROS and MDA, increased the activity of SOD, CAT, and GH-Px, and suppressed the iNOS activity. Furthermore, they reduced TNF- $\alpha$ release and the enzyme activities of COX-II and $\mathrm{PGE}_{2}$ and blocked the NF- $\mathrm{KB}$ signaling pathway $[34,35]$. Furthermore, the crude Premna odorata extract contained daucosterol (4), stigmasterol (9), $\beta$-sitosterol (13), linolenic acid (17), $\beta$-amyrin (24), and arjunolic acid (28) and was reported to block the NF- $\mathrm{kB}$ signaling pathway [36-38] (Table 1, Figure 1). The reported data, ADMET, and ROS antioxidant scavenger activities against the content of various Premna odorata extracts (Figure 2) encourage further in-depth investigation of the plant extract's effect on an inflamed liver. In this study, the hepatic treatment potential of the crude extract of Premna odorata leaves and its fractions (crude, defatted total, n-hex) were investigated on the alcohol-inflamed liver of female Wistar albino rats. The different fractions were chosen according to the obtained crude extract weight $200 \mathrm{~g} / 3 \mathrm{~kg}$ dried leaves and its different fractions (n-hexane, dichloromethane, ethyl acetate, and n-butanol, 20, 3, 5, $70 \mathrm{~g} / 3 \mathrm{~kg}$ dried leaves, respectively) and focusing on the distribution of iridoids, flavones, and polyphenolic metabolites according to the LC-HRESIMS profiling (Table 1, Figure 1).

In response to the alcohol-inflamed liver, bilirubin, AST, ALT, and ALP levels showed a significant increase in their levels, $65.88 \%, 108.53 \%, 33.05 \%$, and $34.04 \%$, respectively, when compared to the negative control group (Table 4). The MDA level showed a significant increase (42.97\%), while the GSH and TAC recorded a significant decrease of $27.42 \%$ and $38.46 \%$, respectively (Table 4 ). Furthermore, CRP, TNF- $\alpha$, ICAM-1, and VCAM-1 parameters showed a significant increase in their levels, 86.96\%, 98.49\%, $114.54 \%$, and $51.72 \%$, respectively, compared to the negative control group (Table 4). Treatment of alcohol-inflamed liver rats with crude, defatted, n-hex extracts showed a significant decrease in bilirubin, AST, ALT, ALP, MDA, CRP, TNF- $\alpha$, VCAM-1, and ICAM levels, as compared to the silymarin-positive 
control group in all treated groups (Table 4) accompanied by a significant increase in the GSH and TAC levels (Table 4). The crude extract showed the highest percentage of improvement for AST (143.23\%), ALP (48.47\%), and MDA (71.07\%). Bilirubin was equally improved upon treatment with crude and n-hex extracts $(58.11 \%)$. On the other hand, the defatted extract showed the highest percentage of improvement for ALT (66.68\%), GSH (50.32\%), and TNF- $\alpha$ (78.18\%) (Table 4). The n-hex extract showed the highest percentage of improvement for the TAC (42.30\%), CRP (86.20\%), and ICAM-1 $(96.36 \%)$. VCAM-1 showed the highest percentage of improvement with defatted and n-hex extracts $(41.37 \%)$. These biochemical findings were also simultaneously substantiated with the histopathological observations described before (Figure 3).

In response to the biochemical parameters above and according to the LC-HRESIMS metabolomic profiling, the n-hex fraction contained sterols, triterpenes, and fatty acids (Table 1, Figure 1). These metabolites have been shown to interfere mainly with the expression of pro-inflammatory cytokines and adhesion molecules by blocking the NF- $\kappa$ B activity [36-38]. We posit this explains the significant effect of the n-hex extract in reducing the serum levels of CRP, TNF- $\alpha$, VCAM-1, and ICAM (Table 4). The defatted extract mainly contained acylated iridoids, flavones, and phenylethanoids, which were mainly acylated with coumaric, P-methoxy cinnamic, or ferulic aromatic acids (Table 1, Figure 1). Having surveyed the relevant literature, defatted extract metabolites were also found to interfere with the expression of pro-inflammatory cytokines and interleukins by blocking the NF- $\kappa B$ activity (especially TNF- $\alpha$ ), their activity increasing with the number of free phenolic $(-\mathrm{OH})$ groups $[8,34,35]$. This phenomenon was observed through the increased TNF- $\alpha$ improving level $(102.56 \%)$ for the defatted extract compared to other treated groups (Table 4$)$. Additionally, the various extracts of Premna odorata showed potential anti-inflammatory activity which improved the severe liver cell inflammation accompanied by chronic alcohol consumption (Table 4).

The significant reduction of MDA levels and enhancement of the TAC and GSH (Table 4) in all treated groups reflected the antioxidant activity for Premna odorata metabolites, especially verbascoside (14). The latter has been reported as an inhibitor of $\mathrm{P}_{450} 2 \mathrm{E}_{1}$ or $\mathrm{CYP}_{2} \mathrm{E}_{1}$, therefore, blocking the MEOS metabolic pathway besides having free radical scavenging effects [39]. The net results showed the improvement of endogenous scavenging of free radicals and the total antioxidant potential, which preserves the structural integrity of hepatocytes [7]. As a result of the anti-inflammatory and antioxidant activities of the Premna odorata extracts, the elevated levels of ALT and AST were markedly reduced, thus suggesting the stabilization of plasma membranes in addition to repairing the hepatocellular damage. Moreover, the decrease of the raised ALP and bilirubin levels indicated the improvement of the biliary dysfunction (Table 4) [7].

According to literature, hepatic treatment investigations were conducted on other Premna species, including the study of hepatoprotection of alcoholic Premna esculenta, Premna corymbosa, Premna serratifolia, and Premna tomentosa leave extracts after liver induction with $\mathrm{CCl}_{4}$. These studies showed significant hepatoprotection by decreasing the activity of serum enzymes, bilirubin, and lipid peroxidation [40-43]. Moreover, the hepatoprotective role of the ethanol Premna integrifolia leave extract on the aflatoxin $B_{1}$-induced toxicity was studied in mice; the study showed the protective effect of Premna integrifolia through the restoration of altered hematological indices and liver marker enzymes [44]. The Premna genus is a natural source for bioactive metabolites having anti-inflammatory and antioxidant properties which have a direct effect on liver inflammation.

\section{Materials and Methods}

\subsection{Chemicals}

The solvents used in this work were $n$-hexane (n-hex.; boiling point (b.p.) $60-80^{\circ} \mathrm{C}$ ), dichloromethane (DCM), ethyl acetate (EtOAC), n-butanol (n-but.), ethanol (EtOH), and $\mathrm{H}_{2} \mathrm{O}_{2}$ purchased from El-Nasr Company for Pharmaceuticals and Chemicals, Egypt. All chemicals for kits (Table 5) were of a high analytical 
grade and purchased from Sigma Chemical Co Ltd. (St Louis, MO, USA). All the kits were produced by Biosystems SA Costa Brava 30, Barcelona (Spain), and DiaSys Diagnostic Systems GmbH, Germany.

Table 5. Kit reagents used in the different experiments.

\begin{tabular}{|c|c|}
\hline Experiment & Kit Reagents \\
\hline ROS & $\begin{array}{l}2^{\prime}, 7^{\prime} \text {-dichlorodihydrofluorescein diacetate }\left(\mathrm{H}_{2} \mathrm{DCF}-\mathrm{DA}\right) \text {, Roswell Park Memorial Institute (RPMI) } 1640 \\
\text { medium, fetal calf serum, penicillin, and streptomycin }\end{array}$ \\
\hline Bilirubin & sulfanilic acid, hydrochloric acid, dimethyl sulfoxide \\
\hline AST & phosphate buffer pH $7.5(100 \mathrm{mmol} / \mathrm{L})$, aspartate $(10 \mathrm{mmol} / \mathrm{L}), \alpha$-ketoglutarate $(2 \mathrm{mmol} / \mathrm{L})$ \\
\hline ALT & alanine $200 \mathrm{mmol} / \mathrm{L}, 2,4$-dinitrophenyl hydrazine $(1 \mathrm{mmol} / \mathrm{L})$ \\
\hline ALP & $\begin{array}{l}\text { standard phenol }(1.59 \mathrm{mmol} / \mathrm{L}) \text {, buffer pH } 10(50 \mathrm{mmol} / \mathrm{L}) \text {, phenyl phosphate }(5 \mathrm{mmol} / \mathrm{L}), \text { EDTA } \\
(100 \mathrm{mmol} / \mathrm{L}), 4 \text {-aminophenazone }(50 \mathrm{mmol} / \mathrm{L}) \text {, potassium ferricyanide }(200 \mathrm{mmol} / \mathrm{L})\end{array}$ \\
\hline MDA & $\begin{array}{l}\text { standard MDA }(10 \mathrm{mmol} / \mathrm{mL}), \begin{array}{c}\text { thiobarbituric acid }(25 \mathrm{mmol} / \mathrm{L}) \text {, detergent }(3 \mathrm{mmol} / \mathrm{L}) \text {, stabilizer } \\
(15 \mathrm{mmol} / \mathrm{L})\end{array}\end{array}$ \\
\hline GSH & DTNB (1 mmol/L) \\
\hline TAC & sulfuric acid, sodium phosphate, ammonium molybdate \\
\hline CRP & $\begin{array}{l}\text { capture antibody-coated microplate: one plate of } 96 \text { wells coated with a rabbit anti-rat CRP antibody } \\
\text { detection antibody/enzyme conjugates }(100 \mathrm{x}) \text { : concentrated horseradish peroxidase (HRP) conjugated to } \\
\text { a rabbit anti-rat CRP antibody containing stabilizers and preservative } \\
\text { standard ( } 10 \mathrm{x}) \text { : rat serum with elevated levels of CRP, wash buffer: powdered phosphate-buffered saline } \\
\text { (PBS) with } 0.05 \% \text { Tween-20, TMB substrate: solution containing } 3,3^{\prime}, 5,5^{\prime} \text {-tetramethylbenzidine (TMB) } \\
\text { stop solution: diluted phosphoric acid }\end{array}$ \\
\hline TNF- $\alpha$ & $\begin{array}{r}\text { Rat TNF- } \alpha \text { microplates - } 96 \text {-well polystyrene microplates (12 strips of } 8 \text { wells) coated with a monoclonal } \\
\text { antibody specific to rat TNF- } \alpha \\
\text { Rat TNF- } \alpha \text { conjugate }-23 \mathrm{~mL} / \text { vial of a polyclonal antibody against the rat TNF- } \alpha \text { conjugated to } \\
\text { horseradish peroxidase with preservatives } \\
\text { Rat TNF- } \alpha \text { standard }-1.5 \mathrm{ng} / \text { vial of the recombinant rat TNF- } \alpha \text { in a buffered protein base with } \\
\text { preservatives, lyophilized }\end{array}$ \\
\hline VCAM-1 & $\begin{array}{l}\text { Pre-coated, ready-to-use 96-well strip plate, plate sealer for } 96 \text { wells, standard diluent, assay diluent A, } \\
\text { assay diluent B, stop solution, standard, detection reagent A, detection reagent B, TMB substrate, } \\
\text { wash buffer ( } 30 \times \text { concentrate); }\end{array}$ \\
\hline ICAM-1 & $\begin{array}{l}\text { Pre-coated 96-well strip microplate, wash buffer, stop solution, assay diluent(s), lyophilized standard, } \\
\text { biotinylated detection antibody, streptavidin-conjugated HRP, TMB One-Step Substrate }\end{array}$ \\
\hline
\end{tabular}

\subsection{Plant Material and Extraction}

Premna odorata leaves were collected at the flowering stage in May 2018 from Zoo, Giza, Egypt. The plant was identified by Abd El-Halim A. Mohammed (Horticultural Research Institute, department of Flora and phytotaxonomy Researchers, Dokki, Cairo, Egypt). A voucher specimen (2018-BuPD 45) was deposited at the department of pharmacognosy, Faculty of Pharmacy, Beni-Suef University, Egypt.

The air-dried leaves $(3 \mathrm{~kg})$ were collected and air-dried in the darkness for one month. After drying, the leaves were finely powdered using a CM 290 Cemotec $^{\mathrm{TM}}$ laboratory grinder $(200-230 \mathrm{~V}, 50-60 \mathrm{~Hz}$, Foss, Denmark). The finely powdered leaves were extracted by maceration without agitation using $70 \%$ ethanol (EtOH), (4 L, 3 X, four days each) at room temperature and subsequently concentrated under vacuum at $40{ }^{\circ} \mathrm{C}$ using a rotary evaporator (Buchi Rotavapor R-300, Cole-Parmer, Vernon Hills, IL, USA) to afford a $200 \mathrm{~g}$ crude extract. A $20 \mathrm{~g}$ aliquot was used for all biological evaluations of the crude extract. Another $2 \mathrm{~g}$ crude extract was suspended in $4 \mathrm{~mL}$ distilled water and successively Kuching-partitioned with solvents of different polarities (n-hex, DCM, EtOAc, and n-but.) for the 
LC-HRESIMS experiment. The remaining $178 \mathrm{~g}$ crude extract was defatted using $\mathrm{n}-\mathrm{hex}(1 \mathrm{~L}, 3 \mathrm{~h}$, $3 \mathrm{X}$ ). The $\mathrm{n}$-hexane extract was dried at $30^{\circ} \mathrm{C}$ using a rotary evaporator (Buchi Rotavapor R-300, Cole-Parmer, Vernon Hills, IL, USA) to obtain the $20 \mathrm{~g}$ used for all biological evaluations of the n-hex extract. The remaining extract now defatted by n-hex was dried and $20 \mathrm{~g}$ were used as the defatted total extract.

\subsection{Metabolomic Analysis Procedure}

The crude extract of Premna odorata leaves and the various fractions (n-hexane, DCM, EtOAc, and n-butanol) were subjected to metabolomic analysis using LC-HRESIMS [45,46]. LC-HRESIMS metabolic analyses were done using an ACQUITY Ultra Performance Liquid Chromatography system coupled with a Synapt $\mathrm{G}_{2}$-HDMS quadrupole-time-of-flight hybrid mass spectrometer (Waters, Milford, MA, USA). Chromatographic separation was carried out on an ethylene bridged hybrid (BEH) $\mathrm{C}_{18}$ column $(2.1 \times 100 \mathrm{~mm}$, particle size $1.7 \mu \mathrm{m}$; Waters, Milford, MA, USA) with a guard column $(2.1 \times 5 \mathrm{~mm}$, particle size $1.7 \mu \mathrm{m})$ and a linear binary solvent gradient of $0-100 \%$ eluent B over $6 \mathrm{~min}$ at a flow rate of $0.3 \mathrm{~mL} / \mathrm{min}^{-1}$ using $0.1 \%$ formic acid in water (v/v) as solvent $\mathrm{A}$ and acetonitrile as solvent B. The injection volume was $2 \mu \mathrm{L}$ and the column temperature was $40^{\circ} \mathrm{C}$. Electrospray ionization (ESI) in the positive mode was used and the source was operated at $120^{\circ} \mathrm{C}$. The ESI capillary voltage was set to $0.8 \mathrm{kV}$, the sampling cone voltage was set to $25 \mathrm{~V}$, and nitrogen (at $350^{\circ} \mathrm{C}$, flow rate (FR) $800 \mathrm{~L} / \mathrm{h}$ ) was used as the desolvation gas and the cone gas (FR $30 \mathrm{~L} / \mathrm{h}$ ). The mass range for the TOF-MS was set according to the mass-to-charge ratio $(\mathrm{m} / \mathrm{z})$ 50-1,200. In MZmine 2.12, the raw data were imported by selecting the ProteoWizard-converted positive files in the mzML format. Ions were detected, followed by a chromatogram builder and a chromatogram deconvolution. The local minimum search algorithm was applied, and isotopes were also identified via the isotopic peaks grouper. The missing peaks were detected using a gap-filling peak finder. An adduct search as well as a complex search were performed. The processed data set was then subjected to molecular formula prediction and peak identification. The positive data set from each of the respective plant extracts were dereplicated against the Dictionary of Natural Products (DNP) database.

\subsection{In Silico ADMET Properties for the Crude Extract of Different Premna odorata Metabolites}

In silico ADMET properties for the metabolites identified by the Premna odorata metabolomics profiling using LC-HRESIMS were defined using the online PreADMET program version 2.0 depending on the 2D structural models drawn in the ChemBioDraw Ultra version 11.0 software (Cambridge Software), including plasma protein binding (PPB), where the drug is considered; chemicals are strongly PPB at $>90 \%$ and weakly at $<90 \%$. The blood-brain barrier (BBB); the drug is considered to have high absorption to the CNS > 2.0 BB (Cbrain/Cblood), moderate absorption to the CNS at 2.0 0.1 BB (Cbrain/Cblood), and low absorption to the CNS at < 0.1 BB (Cbrain/Cblood) [47]. For skin permeability (SP), PreADMET predicts in vitro skin permeability and the result value is given as logKp. $\mathrm{Kp}(\mathrm{cm} / \mathrm{h})$ is defined as follows: $\mathrm{KP}=\frac{\mathrm{km} \times \mathrm{D}}{\mathrm{h}}$, where $\mathrm{Km}$ is the coefficient of distribution between the stratum corneum and the vehicle, $D$ is the average diffusion coefficient $\left(\mathrm{cm}^{2} / \mathrm{h}\right)$, and $h$ is the thickness of skin (cm) [48]. In human intestinal absorption (HIA) [49], the drug is considered a poorly absorbed compound at 0 20\% HIA, a moderately absorbed compound at 20 70\% HIA, and a well-absorbed compound at 70 100\% HIA. In the Caco-2 cell permeability and Madin-Darby canine kidney (MDCK) cell model [50,51], the drug could generally belong to one of three categories: low permeability $<4 \mathrm{P}_{\mathrm{Caco}-2}(\mathrm{~nm} / \mathrm{sec})$, moderate permeability $4 \sim 70 \mathrm{P}_{\mathrm{Caco}-2}(\mathrm{~nm} / \mathrm{sec})$, and high permeability $>70 \mathrm{P}_{\mathrm{Caco}-2}$ $(\mathrm{nm} / \mathrm{sec})$. Permeability glycoprotein $(\mathrm{Pgp})$ is an important protein of the cell membrane that pumps many foreign substances out of cells, and it likely evolved as a defense mechanism against harmful substances [52]. Cytochromes $\mathrm{P}_{450}-2 \mathrm{C}_{19}\left(\mathrm{CYP}_{2} \mathrm{C}_{19}\right), \mathrm{CYP}_{2} \mathrm{C}_{9}$, and $\mathrm{CYP}_{3} \mathrm{~A}_{4}$ are important cytochrome $\mathrm{P}_{450}$ enzymes with a major role in the oxidation of both xenobiotic and endogenous compounds [53]. The Ames test is a simple method of testing mutagenicity of a compound [54]. PreADMET predicts toxicity for TA98, TA100, and TA1535, which are often used in the Ames test. The prediction result is 
positive or negative. Rodent carcinogenicity is a toxicity that causes cancer in the body. PreADMET predicts the result from its model, which is built upon the data of the National Toxicology Program (NTP) and the United States Food and Drug Administration (US FDA), which are the results of the 2-year-long in vivo carcinogenicity tests of mice and rats. Negative prediction indicates clear evidence of carcinogenic activity and positive prediction shows no evidence of carcinogenic activity.

The hERG (the human Ether-à-go-go-Related Gene) is a gene that codes for a protein known as $\mathrm{K}_{\mathrm{v}} 11.1$, the alpha subunit of a potassium ion channel. This ion channel is best known for its contribution to the electrical activity of the heart. The hERG channel mediates the repolarizing $\mathrm{I}_{\mathrm{Kr}}$ current in the cardiac action potential, which helps coordinate the heart's beating [55].

\subsection{In Vitro Measurement of Total Reactive Oxygen Species (ROS)}

\subsubsection{Cell Lines, Culture Conditions}

The Hep G2 human liver cancer cell line was obtained from the American Type Culture Collection, the cells were cultured using Roswell Park Memorial Institute (RPMI 1640 medium supplemented with $10 \%$ fetal calf serum, $100 \mathrm{U} / \mathrm{mL}$ penicillin, and $100 \mu \mathrm{g} / \mathrm{mL}$ streptomycin) in a humidified atmosphere with $7 \% \mathrm{CO}_{2}$ and $93 \%$ air at $37^{\circ} \mathrm{C}$.

\subsubsection{Intracellular ROS Levels Quantification}

ROS inhibition activities of crude, defatted crude, and n-hex Premna odorata extracts were tested against the Hep G2 human liver cancer cell line using the ROS flow cytometry assay [56]. In brief, the cells were placed in a 96-well microtiter plate at a density of $1 \times 10^{4}$ cells per well in a final volume of $100 \mu \mathrm{L}$ of the culture medium. These cells were treated for $24 \mathrm{~h}$ with different Premna odorata extracts (groups 3-5) and silymarin (group 6) using $10 \mu \mathrm{L}$ at $37^{\circ} \mathrm{C}$ with $5 \% \mathrm{CO}_{2}$. After the treatment, the cells were immediately incubated for $24 \mathrm{~h}$ at $37^{\circ} \mathrm{C}$ [56]. The different groups were then treated with $10 \mathrm{mM}$ $2^{\prime}, 7^{\prime}$-dichlorodihydrofluorescein diacetate $\left(\mathrm{H}_{2} \mathrm{DCF}-\mathrm{DA}\right)$ dissolved in the phosphate buffer saline (PBS) $(5.0 \mathrm{mg} / \mathrm{mL})$ at $37^{\circ} \mathrm{C}$ for $20 \mathrm{~min}$. The color reaction was stopped by removing the media and adding $100 \mu \mathrm{L}$ DMSO in each well to dissolve the formed formazan crystals. The incubation at $37^{\circ} \mathrm{C}$ resumed for up to $20 \mathrm{~min}$ to ensure complete dissolution of crystals. The absorbance was determined at $\lambda_{495} \mathrm{~nm}$ using an FLX800 fluorescence microplate reader (BioTEK Instruments, Winooski, VT, USA). $\mathrm{H}_{2} \mathrm{O}_{2}$ was used as the positive control.

\subsection{Animal Treatment}

Female Wistar albino rats (150-170 g) were obtained from the animal house of the National Research Centre, Dokki, Giza, Egypt. The rats were fed using a standard diet and free access to tap water [57]. The rats were housed in polypropylene cages and maintained under controlled conditions of the $12 \mathrm{~h}$ of light/ $12 \mathrm{~h}$ of dark cycle with $50 \%$ relative humidity at 25 to $30^{\circ} \mathrm{C}$ with keeping for two weeks to be acclimatized to the environmental conditions.

\subsection{Animal Ethical Statement}

This study was approved by the Institutional Animal Ethics Committee of the National Research Center which stated that animals should not suffer at any stage of experimentation and be maintained in accordance with the Guide for the care and use of laboratory animals (ethical approval No: 012234).

\subsection{Acute Toxicity Test}

Acute toxicity studies were carried out using female Wistar albino rats as per Organization for Economic Cooperation and Development (OECD) guideline 423 (2001). According to the latter, acute oral toxicity refers to the adverse effects occurring as a result of oral administration of a single dose of a substance or multiple doses given within $24 \mathrm{~h}$ (overnight). Fasted rats were weighed and divided randomly into five groups containing three rats each. As there was no information regarding 
the plant being tested, for animal welfare reasons, the OECD recommends using a starting dose of $300 \mathrm{mg} / \mathrm{kg}$ b.w. If mortality was not observed after $24 \mathrm{~h}$, the previous procedure was repeated for further groups with higher doses: 1000, 2000, 3000, 4000, and $5000 \mathrm{mg} / \mathrm{kg}$ b.w.

\subsection{Induction of Alcohol Liver Inflammation and Experimental Design}

Acute alcohol liver inflammation was induced in rats according to Keegan (2013) [58]. In a brief manner, rats received $2 \%$ sucrose as the sole source of liquid for three days prior to the initiation of $5 \%$ ethanol in $2 \%$ sucrose. The ethanol concentration was increased in increments of $5 \%$ at intervals of four days to a concentration of $15 \%$. Thereafter, weekly increases were made to a final concentration of $40 \%$. Fresh drinking water/ethanol was provided twice weekly. Sixty female Wistar albino rats were divided into six groups each containing ten rats: group 1: healthy rats (negative control); group 2: untreated rats (positive control) euthanized after thirty days; groups 3-5: rats treated orally through gavages with crude, defatted crude and n-hexane extracts, respectively, in the dose of $500 \mathrm{mg} / \mathrm{kg} \mathrm{b} . \mathrm{w}$. for thirty days and then euthanized; group 6: rats treated orally through gavages with the silymarin reference drug [59] using the $200 \mathrm{mg} / \mathrm{kg}$ b.w. dose for thirty days and then euthanized.

\subsubsection{Blood Sampling}

The blood samples were collected in a clean and dry test tube by puncturing of the sublingual vein. Subsequently, allowing the clotting process to last $10 \mathrm{~min}$, they were centrifuged at $108,669 \times g$ for serum separation. The serum was stored at $-80^{\circ} \mathrm{C}$ for further experiments.

\subsubsection{Biochemical Analysis}

The separated serum was used for the following tests: liver function tests: bilirubin was determined according to Walter and Gerade (1970) [60]; AST, ALT were determined according to Reitman and Frankel (1957) [61]; ALP was determined according to Belfield and Goldberg (1971) [62] using bio-diagnostic kits (Egypt); oxidative stress marker and antioxidant tests: MDA was determined according to Santos et al. (1980) [63]; GSH was determined according to Kageyama (1971) [64], and the TAC was determined according to Mclemore et al. (1998) [65]; inflammatory marker and adhesion molecule tests: CRP, TNF- $\alpha$ were determined according to Erhardt et al. (2004) [66] and Perrey et al. (1999) [67], respectively; ICAM-1 and VCAM-1 were determined according to Szarka et al. (2010) [68].

\subsection{Statistical Analysis}

The pooled data were presented as the means \pm standard deviation (SD) for ten rats in each group. The differences between different treatment groups were determined by the ANOVA followed by the Dunnett's test using PASW Statistics ${ }^{\circledR}$ version 18 (Quarry Bay, Hong Kong, China), where an unshared letter is considered significant at $p \leq 0.05$.

$$
\begin{gathered}
\% \text { change }=\frac{\text { mean of negative control }- \text { mean of treatment group }}{\text { mean of negative control }} \times 100 \\
\% \text { improvment }=\frac{\text { mean of positive control }- \text { mean of treatment group }}{\text { mean of negative control }} \times 100
\end{gathered}
$$

\subsection{Histopathological Examination}

The histological sections of the liver for all experimental groups of rats were taken by adopting the procedure described by Gomori (1941) [69]. Briefly, liver slices were taken from all groups and fixed instantaneously in neutral buffered formalin $(10 \%)$ for $24 \mathrm{~h}$, then processed in automatic processors, embedded in paraffin wax (melting point $55-41^{\circ} \mathrm{C}$ ), and paraffin blocks were obtained. Sections of $6 \mu \mathrm{m}$ thickness were prepared and stained with the hematoxylin and eosin (H\&E) stain. The cytoplasm 
stained shades of pink and red, while the nuclei gave a blue color. The slides were examined and photographed under a light microscope at the $\times 150$ magnification power.

\section{Conclusions}

To sum up, our results showed 28 metabolites related to iridoids and polyphenolics; they were dereplicated and their biological relevance was correlated. The crude extract showed better activity in normalizing most of the parameters, indicating its capability to improve the inflamed liver in vitro and in vivo through its antioxidant capabilities, which was clear in all the chemical and histological examinations. The in silico ADMET screening study showed great bioavailability and distribution of different components. These findings support the use of these extracts due to the combined effects of these phytochemicals and/or their synergistic interactions as a natural remedy to improve the inflamed liver function.

Author Contributions: Conceptualization: H.M.H., A.M.O., H.F.A., M.H.H., A.H.E., U.R.A., M.E.R., H.A.A., E.A. Data Curation: A.H.E., H.F.A., U.R.A., M.E.R., H.M.H., A.M.O. Formal analysis: A.H.E., H.F.A., U.R.A., H.A.A. Investigation: A.H.E., E.A., M.H.H., A.B.M., U.R.A., H.M.H., A.M.O., H.A.A., M.E.R. Methodology: H.F.A., M.H.H., A.H.E., U.R.A. Project administration: A.B.M., U.R.A., H.M.H., A.M.O. Resources: H.A.A., E.A., U.R.A., M.E.R. Software: H.E.A., U.R.A., A.H.E., M.E.R. Writing-original draft: A.H.E. Writing-review and editing: H.M.H., A.M.O., H.F.A., M.H.H., A.H.E., U.R.A., M.E.R., H.A.A., E.A. All authors have read and agreed to the published version of the manuscript.

Funding: This project was funded by the Deanship of Scientific Research (DSR), King Abdulaziz University, Jeddah, under grant No. D-273-142-1441.

Acknowledgments: The authors, gratefully acknowledge the DSR's technical and financial support. We thank Martin Müller and Markus Krischke for LC-MS analysis (University of Würzburg), as well as Asmaa AboulMagd for PreADMET analysis (department of pharmaceutical chemistry, Faculty of Pharmacy, Nahda University, Beni-Suef 62514, Egypt).

Conflicts of Interest: No potential conflict of interest was reported by the authors.

\section{References}

1. Conti, A.; Gulì, C.; La Torre, D.; Tomasello, C.; Angileri, F.F.; Aguennouz, M.H. Role of inflammation and oxidative stress mediators in gliomas. Cancers 2010, 2, 693-712. [CrossRef] [PubMed]

2. Marsano, L.S.; Mendez, C.; Hill, D.; Barve, S.; Mcclain, C.J. Diagnosis and treatment of alcoholic liver disease and its complications. Alcohol Res. 2003, 27, 247-256.

3. Ashley, N.T.; Weil, Z.M.; Nelson, R.J. Inflammation: Mechanisms, costs, and natural variation. Rev. Ecolo. Evol. Syst. 2012, 43, 385-406. [CrossRef]

4. Birben, E.; Sahiner, U.M.; Sackesen, C.; Erzurum, S.; Kalayci, O. Oxidative stress and antioxidant defense. World Allergy Organ. J. 2012, 5, 9-19. [CrossRef]

5. Mukherjee, S. Alcohol metabolism and generation of free radicals: A deep insight. Oa Alcohol. 2014, 2, 10.

6. Bishayee, A.; Darvesh, A.S.; Politis, T.; McGory, R. Resveratrol and liver disease: From bench to bedside and community. Liver Int. 2010, 30, 1103-1114. [CrossRef]

7. Abdelhafez, O.H.; Fawzy, M.A.; Fahim, J.R.; Desoukey, S.Y.; Krischke, M.; Mueller, M.J.; Abdelmohsen, U.R. Hepatoprotective potential of Malvaviscus arboreus against carbon tetrachloride-induced liver injury in rats. PLoS ONE 2018, 13, e0202362. [CrossRef]

8. Pinzon, L.C.; Uy, M.M.; Sze, K.H.; Wang, M.; Chu, I.K. Isolation and characterization of antimicrobial, anti-inflammatory and chemopreventive flavones from Premna odorata Blanco. J. Med. Plant Res. 2011, 5, 2729-2735.

9. Elmaidomy, A.H.; Mohyeldin, M.M.; Ibrahim, M.M.; Hassan, H.M.; Amin, E.; Rateb, M.E.; Hetta, M.H.; El Sayed, K.A. Acylated iridoids and rhamnopyranoses from premna odorata (lamiaceae) as novel mesenchymal-epithelial transition factor receptor inhibitors for the control of breast cancer. Phytother. Res. 2017, 31, 1546-1556. [CrossRef]

10. Otsuka, H.; Kashima, N.; Hayashi, T.; Kubo, N.; Yamasaki, K.; Padolina, W.G. Premnaodorosides A, B and C, iridoid glucoside diesters of an acyclic monoterpenediol from leaves of Premna odorata. Phytochemistry 1992, 31, 3129-3133. [CrossRef] 
11. Otsuka, H.; Kubo, N.; Yamasaki, K.; Padolina, W.G. Premnosides A-D: Diacyl 6-O- $\alpha$-Lrhamnopyranosylcatalpols from Premna odorata. Phytochemistry 1989, 28, 3063-3067. [CrossRef]

12. Otsuka, H.; Kubo, N.; Yamasaki, K.; Padolina, W.G. Two iridoid glycoside caffeoyl esters from Premna odorata. Phytochemistry 1989, 28, 513-515. [CrossRef]

13. El-Mudomy, A.H.; Hassan, H.M.; Amin, E.; Mohamed, W.A.; Hetta, M.H. Chemical composition and in vivo anti-inflammatory activity of the lipid extract from Premna odorata Blanco cultivated in Egypt. World J. Pharm. Pharm. Sci. 2015, 5, 129-135.

14. Elmaidomy, A.H.; Hassan, H.M.; Amin, E.; Mohamed, W.; Hetta, M.H. Premna odorata volatile oil as a new mycobacterium tuberculosis growth inhibitor for the control of tuberculosis disease. Eur. J. Med. Plants 2017, 21, 1-11. [CrossRef]

15. Waleed, A.; Samah, S.; Mona, F.; Abeer, H.; Hossam, M.; Elham, A.; Mona, H. Immunomodulatory effect of Premna odorata volatile oils in Mycobacterium tuberculosis by inhibiting TLR4/NF-kB pathway. J. Herbmed. Pharmacol. 2019, 8, 1-7.

16. Tantengco, O.A.G.; Jacinto, S.D. Cytotoxic activity of crude extracts and fractions from Premna odorata (Blanco), Artocarpus camansi (Blanco) and Gliricidia sepium (Jacq.) against selected human cancer cell lines. Asian Pac. J. Trop. Biomed. 2015, 5, 1037-1041. [CrossRef]

17. Harborne, J.B. The flavonoids: Advances in Research Since 1980; CRC press Taylor and Francis Group: New York, NY, USA, 2013.

18. Otsuka, H.; Kubo, N.; Sasaki, Y.; Yamasaki, K.; Takeda, Y.; Seki, T. Iridoid diglycoside monoacyl esters from stems of Premna japonica. Phytochemistry 1991, 30, 1917-1920. [CrossRef]

19. Lirio, S.B.; Macabeo, A.P.G.; Paragas, E.M.; Knorn, M.; Kohls, P.; Franzblau, S.G.; Wang, Y.; Aguinaldo, M.A.M. Antitubercular constituents from Premna odorata Blanco. J. Ethnopharmacol. 2014, 154, 471-474. [CrossRef]

20. Sudo, H.; Takushi, A.; Hirata, E.; Ide, T.; Otsuka, H.; Takeda, Y. Premnaodorosides D-G: Acyclic monoterpenediols iridoid glucoside diesters from leaves of Premna subscandens. Phytochemistry 1999, 52, 1495-1499. [CrossRef]

21. Otsuka, H.; Watanabe, E.; Yuasa, K.; Ogimi, C.; Takushi, A.; Takeda, Y. verbascoside iridoid glucoside conjugate from Premna corymbosa var. obtusifolia. Phytochem. 1993, 4, 983-986. [CrossRef]

22. Zhan, Z.J.; Tang, L.; Shan, W.G. A new triterpene glycoside from Premna microphylla. Chem. Nat. Compd. 2009, 45, 197-199. [CrossRef]

23. Carballo-Villalobos, A.; González-Trujano, M.; López-Muñoz, F. Evidence of mechanism of action of anti-inflammatory/antinociceptive activities of acacetin. Eur. J. Pain 2014, 18, 396-405. [CrossRef]

24. Singh, S.S. Preclinical pharmacokinetics: An approach towards safer and efficacious drugs. Curr. Drug Metab. 2006, 7, 165-182. [CrossRef] [PubMed]

25. Fitzpatrick, F.; Wynalda, M. Albumin-lipid interactions: Prostaglandin stability as a probe for characterizing binding sites on vertebrate albumins. Biochemistry 1981, 20, 6129-6134. [CrossRef] [PubMed]

26. Benson, H.A. Transdermal drug delivery: Penetration enhancement techniques. Curr. Drug Delivery 2005, 2, 23-33. [CrossRef] [PubMed]

27. Watkins, C.L.; Brennan, P.; Fegan, C.; Takayama, K.; Nakase, I.; Futaki, S.; Jones, A.T. Cellular uptake, distribution and cytotoxicity of the hydrophobic cell penetrating peptide sequence PFVYLI linked to the proapoptotic domain peptide PAD. J. Control. Release 2009, 140, 237-244. [CrossRef]

28. Zakhari, S. Overview: How is alcohol metabolized by the body? Alcohol Res. 2006, 29, 245.

29. Edenberg, H.J. The genetics of alcohol metabolism: Role of alcohol dehydrogenase and aldehyde dehydrogenase variants. Alcohol Res. 2007, 30, 5 .

30. Nikfarjam, B.A.; Hajiali, F.; Adineh, M.; Nassiri-Asl, M. Anti-inflammatory Effects of Quercetin and Vitexin on Activated Human Peripheral Blood Neutrophils:-The effects of quercetin and vitexin on human neutrophils. J. Pharmacopunct. 2017, 20, 127.

31. Lee, J.-H.; Zhou, H.Y.; Cho, S.Y.; Kim, Y.S.; Lee, Y.S.; Jeong, C.S. Anti-inflammatory mechanisms of apigenin: Inhibition of cyclooxygenase-2 expression, adhesion of monocytes to human umbilical vein endothelial cells, and expression of cellular adhesion molecules. Arch. Pharmacal Res. 2007, 30, 1318-1327. [CrossRef]

32. Yang, Y.; Gong, X.-B.; Huang, L.-G.; Wang, Z.-X.; Wan, R.-Z.; Zhang, P.; Zhang, Q.-Y.; Chen, Z.; Zhang, B.-S. Diosmetin exerts anti-oxidative, anti-inflammatory and anti-apoptotic effects to protect against endotoxin-induced acute hepatic failure in mice. Oncotarget 2017, 8, 30723. [CrossRef] 
33. Jeon, I.H.; Kim, H.S.; Kang, H.J.; Lee, H.S.; Jeong, S.I.; Kim, S.J.; Jang, S.I. Anti-inflammatory and antipruritic effects of luteolin from perilla ( $p$. Frutescens 1.) Leaves. Molecules 2014, 19, 6941-6951. [CrossRef]

34. Viljoen, A.; Mncwangi, N.; Vermaak, I. Anti-inflammatory iridoids of botanical origin. Curr. Med. Chem. 2012, 19, 2104-2127. [CrossRef]

35. Wang, C.; Gong, X.; Bo, A.; Zhang, L.; Zhang, M.; Zang, E.; Zhang, C.; Li, M. Iridoids: Research advances in their phytochemistry, biological activities, and pharmacokinetics. Molecules 2020, 25, 287. [CrossRef]

36. Han, N.; Bakovic, M. Biologically active triterpenoids and their cardioprotective and anti-inflammatory effects. J. Bioanal. Biomed. S. 2015, 12, 1948-1955.

37. Cheon, J.H.; Kim, J.S.; Kim, J.M.; Kim, N.; Jung, H.C.; Song, I.S. Plant sterol guggulsterone inhibits nuclear factor- $\kappa \mathrm{B}$ signaling in intestinal epithelial cells by blocking IкB kinase and ameliorates acute murine colitis. Inflamm. Bowel Dis. 2006, 12, 1152-1161. [CrossRef] [PubMed]

38. Planavila, A.; Laguna, J.C.; Vázquez-Carrera, M. Nuclear factor-кB activation leads to down-regulation of fatty acid oxidation during cardiac hypertrophy. J. Biol. Chem. 2005, 280, 17464-17471. [CrossRef] [PubMed]

39. Lee, K.J.; Woo, E.R.; Choi, C.Y.; Shin, D.W.; Lee, D.G.; You, H.J.; Jeong, H.G. Protective effect of acteoside on carbon tetrachloride induced hepatotoxicity. Life Sci. 2004, 74, 1051-1064. [CrossRef] [PubMed]

40. Bachar, S.; Mahmud, Z.; Qais, N. Antioxidant and hepatoprotective activities of ethanolic extracts of leaves of Premna esculenta Roxb. against carbon tetrachloride-induced liver damage in rats. J. Young Pharm. 2012, 4, 228-234. [CrossRef] [PubMed]

41. Karthikeyan, M.; Deepa, K. Hepatoprotective effect of Premna corymbosa (Burm. f.) Rottl. and Willd. leaves extract on CCl4 induced hepatic damage in Wistar albino rats. Asian Pac. J. Trop. Med. 2010, 3, 17-20. [CrossRef]

42. Vadivu, R.; Suresh, A.J.; Girinath, K.; Kannan, P.B.; Vimala, R.; Kumar, N.S. Evaluation of hepatoprotective and in-vitro cytotoxic activity of leaves of Premna serratifolia Linn. J. Sci. Res. 2009, 1, 145-152. [CrossRef]

43. Devi, K.P.; Sreepriya, M.; Balakrishna, K.; Devaki, T. Protective effect of Premna tomentosa extract (L. verbanacae) on acetaminophen-induced mitochondrial dysfunction in rats. Mol. Cell. Biochem. 2005, 272, 171-177. [CrossRef] [PubMed]

44. Singh, C.; Prakash, C.; Mishra, P.; Tiwari, K.N.; Mishra, S.K.; More, R.S.; Kumar, V.; Singh, J. Hepatoprotective efficacy of Premna integrifolia L. leaves against aflatoxin B1-induced toxicity in mice. Toxicon 2019, 166, 88-100. [CrossRef] [PubMed]

45. Abdelmohsen, U.R.; Cheng, C.; Viegelmann, C.; Zhang, T.; Grkovic, T.; Ahmed, S.; Quinn, R.J.; Hentschel, U.; Edrada-Ebel, R. Dereplication strategies for targeted isolation of new antitrypanosomal actinosporins A and B from a marine sponge associated Actinokineospora sp. EG49. Mar. Drugs 2014, 12, 1220-1244. [CrossRef]

46. Elmaidomy, A.H.; Mohammed, R.M.; Hassan, H.I.; Owis, A.E.; Rateb, M.A.; Khanfar, M.; Krischke, M.J.; Mueller, M.; Ramadan Abdelmohsen, U. Metabolomic Profiling and Cytotoxic Tetrahydrofurofuran Lignans Investigations from Premna Odorata Blanco. Metabolites 2019, 9, 223.

47. Ma, X.-L.; Chen, C.; Yang, J. Predictive model of blood-brain barrier penetration of organic compounds. Acta Pharmacol. Sin. 2005, 26, 500-512. [CrossRef]

48. Singh, S.; Singh, J. Transdermal drug delivery by passive diffusion and iontophoresis: A review. Med. Res. Rev. 1993, 13, 569-621. [CrossRef]

49. Zhao, Y.H.; Le, J.; Abraham, M.H.; Hersey, A.; Eddershaw, P.J.; Luscombe, C.N.; Boutina, D.; Beck, G.; Sherborne, B.; Cooper, I. Evaluation of human intestinal absorption data and subsequent derivation of a quantitative structure-activity relationship (QSAR) with the Abraham descriptors. J. Pharm. Sci. 2001, 90, 749-784. [CrossRef]

50. Yamashita, S.; Furubayashi, T.; Kataoka, M.; Sakane, T.; Sezaki, H.; Tokuda, H. Optimized conditions for prediction of intestinal drug permeability using Caco-2 cells. Eur. J. Pharm. Sci. 2000, 10, 195-204. [CrossRef]

51. Yee, S. In vitro permeability across Caco-2 cells (colonic) can predict in vivo (small intestinal) absorption in man-Fact or myth. Pharm. Res. 1997, 14, 763-766. [CrossRef]

52. Chan, L.M.; Lowes, S.; Hirst, B.H. The ABCs of drug transport in intestine and liver: Efflux proteins limiting drug absorption and bioavailability. Eur. J. Pharm. Sc. 2004, 21, 25-51. [CrossRef] [PubMed]

53. Pelkonen, O.; Turpeinen, M.; Hakkola, J.; Honkakoski, P.; Hukkanen, J.; Raunio, H. Inhibition and induction of human cytochrome $\mathrm{P}_{450}$ enzymes: Current status. Arch. Toxicol. 2008, 82, 667-715. [CrossRef] [PubMed]

54. Creager, A.N.; Boudia, S.; Jas, N. The political life of mutagens: A history of the Ames test. Identifying Mutat. 2014, 285, 1-19. 
55. Cherubini, A.; Hofmann, G.; Pillozzi, S.; Guasti, L.; Crociani, O.; Cilia, E.; Di Stefano, P.; Degani, S.; Balzi, M.; Olivotto, M. Human ether-a-go-go-related gene 1 channels are physically linked to $\beta 1$ integrins and modulate adhesion-dependent signaling. Mol. Biol. Cell 2005, 16, 2972-2983. [CrossRef]

56. Armentano, M.F.; Bisaccia, F.; Miglionico, R.; Russo, D.; Nolfi, N.; Carmosino, M.; Andrade, P.B.; Valentão, P.; Diop, M.S.; Milella, L. Antioxidant and proapoptotic activities of Sclerocarya birrea [(A. Rich.) Hochst.] methanolic root extract on the hepatocellular carcinoma cell line HepG2. Biomed Res. Int. 2015, 2015, 561589. [CrossRef] [PubMed]

57. Dudgeon, D.; Arthington, A.H.; Gessner, M.O.; Kawabata, Z.I.; Knowler, D.J.; Lévêque, C.; Naiman, R.J.; Prieur-Richard, A.H.; Soto, D.; Stiassny, M.L. Freshwater biodiversity: Importance, threats, status and conservation challenges. Biol. Rev. 2006, 81, 163-182. [CrossRef]

58. Keegan, D. Foundations of Distance Education; Routledge Taylor and Francis Group: New York, NY, USA, 2013.

59. Gangarapu, V.; Gujjala, S.; Korivi, R.; Pala, I. Combined effect of curcumin and vitamin E against $\mathrm{CCl}_{4}$ induced liver injury in rats. Am. J. Life Sci. 2013, 1, 117-124. [CrossRef]

60. Walter, M.; Gerade, H. A colorimetric method for determination of total bilirubin. Microchem. J. 1970, 15, 231.

61. Reitman, S.; Frankel, S. A colorimetric method for the determination of serum glutamic oxalacetic and glutamic pyruvic transaminases. Am. J. Clin. Pathol. 1957, 28, 56-63. [CrossRef]

62. Belfield, A.; Goldberg, D.M. Colorimetric determination of alkaline phosphatase activity. Enzyme. 1971, 12, 561-568. [CrossRef] [PubMed]

63. Santos, M.T.; Valles, J.; Aznar, J.; Vilches, J. Determination of plasma malondialdehyde like material and its clinical application in stroke patients. Am. J. Clin. Pathol. 1980, 33, 973-976. [CrossRef] [PubMed]

64. Kageyama, N. A direct colorimetric determination of uric acid in serum and urine with uricase-catalase system. Clin. Chim. Acta. 1971, 31, 421-426. [CrossRef]

65. McLemore, J.L.; Beeley, P.; Thorton, K.; Morrisroe, K.; Blackwell, W.; Dasgupta, A. Rapid automated determination of lipid hydroperoxide concentrations and total antioxidant status of serum samples from patients infected with HIV: Elevated lipid hydroperoxide concentrations and depleted total antioxidant capacity of serum samples. Am. J. Clin. Pathol. 1998, 109, 268-273. [CrossRef]

66. Erhardt, J.G.; Estes, J.E.; Pfeiffer, C.M.; Biesalski, H.K.; Craft, N.E. Combined measurement of ferritin, soluble transferrin receptor, retinol binding protein, and C-reactive protein by an inexpensive, sensitive, and simple sandwich enzyme-linked immunosorbent assay technique. J. Nut. 2004, 134, 3127-3132. [CrossRef] [PubMed]

67. Perrey, C.; Turner, S.J.; Pravica, V.; Howell, W.M.; Hutchinson, I.V. ARMS-PCR methodologies to determine IL-10, TNF- $\alpha$, TNF- $\beta$ and TGF- $\beta 1$ gene polymorphisms. Transplant. Immunol. 1999, 7, 127-128. [CrossRef]

68. Szarka, A.; Rigo, J.; Lazar, L.; Beko, G.; Molvarec, A. Circulating cytokines, chemokines and adhesion molecules in normal pregnancy and preeclampsia determined by multiplex suspension array. BMC Immunol. 2010, 11, 59. [CrossRef]

69. Gomori, G. Observations with differential stains on human islets of Langerhans. Am. J. Pathol. 1941, 17, 395.

(C) 2020 by the authors. Licensee MDPI, Basel, Switzerland. This article is an open access article distributed under the terms and conditions of the Creative Commons Attribution (CC BY) license (http://creativecommons.org/licenses/by/4.0/). 